\title{
UMA METODOLOGIA PARA QUANTIFICAÇÃO DE CO-VÍTIMAS DE HOMICÍDIOS NO BRASIL
}

Fernanda Lira Goes Marina Barros de Oliveira

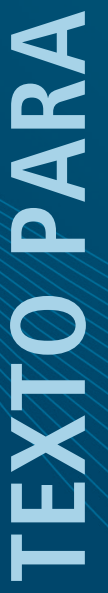





\section{TEXTO PARA DISCUSSÃO}

Brasília, abril de 2021

\section{UMA METODOLOGIA PARA QUANTIFICAÇÃO DE CO-VÍTIMAS DE HOMICÍDIOS NO BRASIL ${ }^{1,2}$}

Fernanda Lira Goes ${ }^{3}$

Marina Barros de Oliveira ${ }^{4}$

1. Esta pesquisa, ainda que seja o aprofundamento de uma primeira metodologia executada no Texto para Discussão no 2489, é também produto de uma parceria por meio de uma aproximação da Unicef no Brasil ao Ipea. Portanto, agradecemos aos colegas na Unicef pelo interesse no assunto e pela dedicação na valorização da vida humana, em especial a Danilo Moura (Monitoring and Evaluation Officer).

2. As autoras agradecem as contribuições com exímio valor que nos foram oferecidas pelas/os colegas no Ipea nas diretorias de Estudos e Políticas Sociais (Disoc) e de Estudos e Políticas do Estado, das Instituições e da Democracia (Diest), principalmente: Luciana Mendes Santos Servo, Fabíola Sulpino Vieira, Luana Simões Pinheiro e Helder Rogério Santana Ferreira. 3. Técnica de planejamento e pesquisa na Disoc/lpea.

4. Pesquisadora do Programa de Pesquisa para o Desenvolvimento Nacional (PNPD) na Disoc/lpea. 


\section{Governo Federal}

Ministério da Economia

Ministro Paulo Guedes

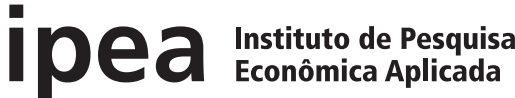

Fundação pública vinculada ao Ministério da Economia, o Ipea fornece suporte técnico e institucional às ações governamentais - possibilitando a formulação de inúmeras políticas públicas e programas de desenvolvimento brasileiros - e disponibiliza, para a sociedade, pesquisas e estudos realizados por seus técnicos.

Presidente

Carlos von Doellinger

Diretor de Desenvolvimento Institucional

Manoel Rodrigues Junior

Diretora de Estudos e Políticas do Estado, das Instituições e da Democracia

Flávia de Holanda Schmidt

Diretor de Estudos e Políticas

Macroeconômicas

José Ronaldo de Castro Souza Júnior

Diretor de Estudos e Políticas Regionais, Urbanas e Ambientais

Nilo Luiz Saccaro Júnior

Diretor de Estudos e Políticas Setoriais de Inovação e Infraestrutura

André Tortato Rauen

Diretora de Estudos e Políticas Sociais

Lenita Maria Turchi

Diretor de Estudos e Relações Econômicas

e Políticas Internacionais

Ivan Tiago Machado Oliveira

Assessor-chefe de Imprensa e Comunicação André Reis Diniz

Ouvidoria: http://www.ipea.gov.br/ouvidoria

URL: http://www.ipea.gov.br

\section{Texto para Discussão}

Publicação seriada que divulga resultados de estudos e pesquisas em desenvolvimento pelo Ipea com o objetivo de fomentar o debate e oferecer subsídios à formulação e avaliação de políticas públicas.

(C) Instituto de Pesquisa Econômica Aplicada - ipea 2021

Texto para discussão / Instituto de Pesquisa Econômica Aplicada.- Brasília : Rio de Janeiro : Ipea , 1990-

ISSN 1415-4765

1.Brasil. 2.Aspectos Econômicos. 3.Aspectos Sociais. I. Instituto de Pesquisa Econômica Aplicada.

CDD 330.908

As publicações do Ipea estão disponíveis para download gratuito nos formatos PDF (todas) e EPUB (livros e periódicos).

Acesse: http://www.ipea.gov.br/portal/publicacoes

As opiniões emitidas nesta publicação são de exclusiva e inteira responsabilidade dos autores, não exprimindo, necessariamente, o ponto de vista do Instituto de Pesquisa Econômica Aplicada ou do Ministério da Economia.

É permitida a reprodução deste texto e dos dados nele contidos, desde que citada a fonte. Reproduções para fins comerciais são proibidas.

JEL: C13. 


\section{SUMÁRIO}

SINOPSE

ABSTRACT

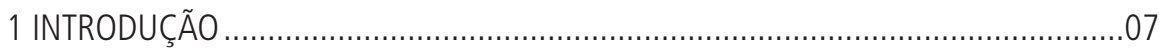

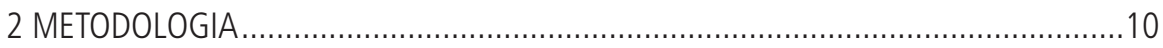

3 RESULTADOS BASEADOS EM INFORMAÇÕES DE PESQUISAS

DOMICILIARES E REFERENTES A HOMICÍDIOS NO BRASIL ..................................17

4 RESULTADOS COM PROTOCOLO DE BOGOTÁ ....................................................39

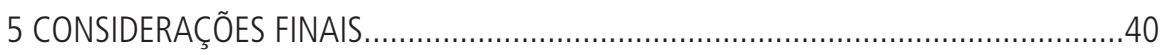

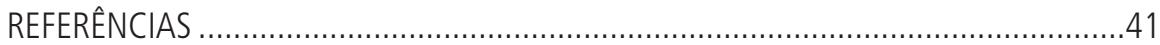





\section{SINOPSE}

Com a realização de uma primeira quantificação de sobreviventes a homicídios no Brasil publicada no Texto para Discussão no 2489 (Goes e Lopes, 2019), nos dedicamos à elaboração de uma segunda metodologia, próxima à primeira, para quantificar grupos populacionais específicos por raça, cor, faixa etária e sexo de pessoas sobreviventes indiretas ou co-vítimas. A metodologia escolhida calculou sobreviventes com base na elaboração de um multiplicador. Para obter o total populacional, nos apoiamos nos dados da Pesquisa Nacional por Amostra de Domicílios Contínua (PNAD), realizada pelo Instituto Brasileiro de Geografia e Estatística (IBGE); para informaçôes referentes aos homicídios, nos atemos aos dados do Sistema de Informação sobre Mortalidade (SIM), do Ministério da Saúde. A escala geográfica usada na pesquisa foi realizada por meio do recorte de municípios, Unidades da Federação e Brasil.

Palavras-chave: jovens negros; homicídio contra crianças; população negra; sobreviventes; co-vítimas. 



\section{INTRODUÇÃO}

A nossa primeira metodologia para propor uma noção da quantidade de pessoas sobreviventes às situações de homicídios foi apresentada no Texto para Discussão no 2489 (Goes e Lopes, 2019). Nessa pesquisa o objetivo específico era refletir sobre uma estimativa que calculasse a quantidade de vítimas indiretas aos homicídios perpetrados contra a população negra no Brasil. Adultos e jovens negros de sexo masculino foram as principais vítimas de homicídios no Brasil desde o início do século XXI (Waiselfisz, 2012; 2013).

Uma das explicaçóes para a concentração e tendência de aumento dos homicídios contra a população negra está assentada no projeto identificado por Nascimento (2016), ainda nos anos 1970, de um modelo genocida de sociedade. De acordo com Mbembe (2018), os aspectos mais presentes na configuração soberana pela necropolítica reforçam uma violência alicerçada pelo modo coletivo de vivência assegurado pela decisão da morte a ser perpetrada contra um grupo específico. O poder é a categoria de ação, de coação e de reação com base na estrutura da violência sistêmica. Nas análises sobre o poder no limite máximo da violência estrutural imposta pelas opressóes físicas e psicológicas do Estado, inclusive e majoritariamente, o sujeito a impor o poder, o colonizador, harmoniza a manutenção costumeira da morte sobre a população colonizada (Fanon, 2005). As relações entre uma violência estrutural, a ação; sujeitos violentadores, a coação; e diversas vítimas, as reações, estão explicitas nos dados oficiais dos homicídios no Brasil.

Nesse sentido pressupóe-se ponderar um perfil das pessoas que tenham suas experiências de vida no século XXI determinadas pela probabilidade de perder alguém para um ato de homicídio. Quantificar as vítimas indiretas é importante para, conscientemente, diminuir, evitar e, finalmente, pôr fim, ou seja, encerrar uma taxa de homicídios que vem se mantendo alta no país. Talvez esse seja o primeiro acordo coletivo com relação a esse estado de violência - ampliar a capacidade de estabelecer costumes pelos quais outros meios diversos ao hábito de homicídio sejam a prioridade nas relaçóes sociais, incentivar o diálogo para além das divergências e diferenças enquanto instrumento de solução de controvérsias e, mais, promover a consciência do ato violento.

Uma vez divulgada, a primeira estimativa quantificada no Ipea recebeu algumas indicaçôes para avançar na pesquisa. Sugeriu-se que se elaborassem outros exercícios com classificações não calculadas inicialmente. A continuidade dos esforços para estimar as 
pessoas impactadas por homicídios, conceituadas como co-vítimas, vítimas indiretas ou sobreviventes (Hertz, Prothrow-Stith e Chery, 2005) responde ao cenário nacional com a manutenção de elevados indicadores de homicídio (Cerqueira et al., 2018).

Primeiramente, em uma aproximação com o Fundo das Naçôes Unidas para a Infância (Unicef) no Brasil, nos foi demandado direcionar o recorte geracional para um grupo específico de pessoas em idades como crianças e adolescentes. Em segundo lugar, após apresentação em evento interno no Ipea durante um Seminário das Quintas, realizado em novembro de 2019, nos foi demandado ampliar o recorte racial para além dos homicídios contra negros, estimar também a quantidade de pessoas co-vítimas brancas relacionadas aos homicídios contra pessoas brancas.

Diante dessas demandas, continuamos o estudo anterior. Não apenas pelo tema em si, mas porque, em razáo de limites de metodologias, replicamos alguns dos exercícios realizados com os grupos raciais. Um segundo conjunto de metodologias para estimar vítimas indiretas ou co-vítimas de homicídios relacionados a alguém que residia no mesmo domicílio no Brasil é então apresentado aqui.

Entre as pesquisas acerca dos homicídios perpetrados no Brasil desde 1998, uma série de estudos no âmbito do Mapa da Violência acompanham o diagnóstico do problema. A tendência de maior quantidade de vítimas homens, de raça/cor negra, e jovens, com idade entre 15 a 29 anos, foi apontada por Waiselfisz $(2012 ; 2013){ }^{1}$

No Ipea, a contribuição se faz por diversos aspectos específicos sintetizados com a atualização dos dados e das categorias no Atlas da Violência iniciado em $2016,{ }^{2}$ no qual o recorte por idade, por raça/cor, e por sexo estáo expressos de modo a desagregar os dados e enriquecer as análises. Os estudos ainda se debruçam por categorias específicas de homicídios e outras violências como mortes no trânsito, suicídio, mortes por causas indeterminadas e por armas de fogo, crimes violentos contra a pessoa e contra o patrimônio, acidentes de transporte e gastos com política de segurança pública. A

1. As diversas edições do Mapa da Violência podem ser acessadas em: <http://flacso.org.br/?project=mapa-da-violencia>. 2. 0 Atlas da Violência é um projeto interno ao Ipea, com parcerias externas, que vai além das publicações anuais. No site do Atlas é possível acessar artigos escritos por pesquisadores do Ipea e demais órgãos e instituições parceiras; baixar os dados de homicídio corrigidos por variáveis como sexo, raça/cor, idade; baixar as tabelas elaboradas para uso de outras/os pesquisadoras/es. Disponível em: <http://www.ipea.gov.br/atlasviolencia/>. 
geografia presente no Atlas disponibiliza os dados com algumas publicaçôes específicas por municípios, Unidades Federativas (UFs) e para o Brasil.

Para além do Atlas da Violência, o acúmulo de pesquisas apresentadas no Ipea acerca de questốes relacionadas à segurança e, especificamente, sobre homicídios podem ser classificadas em três grupos: i) as pesquisas diretamente ligadas ao tema dos homicídios; ii) as pesquisas com intersecção entre as questôes de homicídios e outras políticas públicas; e iii) as pesquisas específicas relacionadas aos homicídios impostos pela violência perpetrada contra a mulher. Não elaboramos um resumo de cada trabalho, mas indicamos a disponibilidade, principalmente de Textos para Discussão, para que haja conhecimento e apropriação de um engajamento anterior a esta pesquisa acerca de temas diretamente relacionados. A importância de explicitar os demais trabalhos de colegas está assentada na ideia de que pensar estimativas de pessoas afetadas por homicídio só é possível mediante o acúmulo de trabalhos dentro e fora do Ipea, que permitem avançar e oferecer uma colaboração ainda que de modo pontual.

Os primeiros estudos nos quais os homicídios são temas principais iniciaram desde 2003 (Cerqueira e Lobão, 2003a). ${ }^{3}$ Não apenas o aumento de casos de homicídios foi motivo de atenção de estudos, como também algumas especificidades relacionadas ao perfil das vítimas e a qualidade das informaçôes. A diferença de casos de homicídios classificados como causa indeterminada, homicídios ocultos, foram corrigidos em mais de 18,3\% (Cerqueira, 2013).

O segundo grupo de estudos trata da questão diante de uma intersecção entre o problema de homicídios e demais políticas públicas. A correlação com a violência foi abordada em estudos sobre moradia, especialmente na cidade de Sáo Paulo (Rodrigues, 2006), programa de distribuiçâo de renda (Thomé e Vonbun, 2017) e na análise de variáveis de trabalho, como a taxa de desemprego e renda, e de acesso à educaçáo como possibilidade de alteração do cenário de homicídios no Brasil (Cerqueira e Moura, 2019).

3. Outras pesquisas diretas sobre homicídios apresentadas em formatos de Textos para Discussão são relevantes ao conhecimento acerca da questão e estão disponíveis no site do Ipea para acesso gratuito: (Cerqueira e Lobão, 2003b; Carvalho, Cerqueira e Lobão, 2005; Cerqueira, Lobão e Carvalho, 2005; Carvalho et al., 2007; Rivero, 2010; Moura, 2010; Carvalho et al., 2011; Cerqueira, 2012; Rodrigues e Rivero, 2012; Cerqueira e Mello, 2012; Cerqueira, 2013; Cerqueira, 2013; Pessoa, 2016; Cerqueira e Coelho, 2017; Cerqueira et al., 2020). 
A relação entre homicídio e mulheres foi pesquisado por Garcia e Silva (2016) no contexto de aproximaçóes entre a vítima e pessoas conhecidas, geralmente homens, enquanto determinante no avanço das perspectivas sobre o crime de feminicídio. ${ }^{4}$ Ademais, abordou-se uma avaliação mais específica da Lei Maria da Penha ${ }^{5}$ enquanto variável aos incidentes de violência doméstica perpetrados contra mulheres (Cerqueira, 2015). O estado da arte específico ao Ipea se desenvolve de modo diverso, seja com relação aos temas tratados nas pesquisas, às metodologias e os resultados concluídos, seja no tocante às recomendaçôes de políticas públicas.

\section{METODOLOGIA}

Para estimar uma determinada quantidade de pessoas afetadas por homicídios no Brasil, aqui chamadas de sobreviventes, usamos duas bases de dados que compóem de um lado o perfil populacional, e de outro o perfil das vítimas de homicídio - ou seja, informaçóes de caráter público, coerentes com o desenho da estimativa. Para obter o total populacional, nos apoiamos nos dados da Pesquisa Nacional por Amostra de Domicílios Contínua (PNAD), realizada pelo Instituto Brasileiro de Geografia e Estatística (IBGE); e, para informações referentes aos homicídios, nos atemos aos dados do Sistema de Informação sobre Mortalidade (SIM), do Ministério da Saúde.

Desenhamos nosso percurso por meio de nove exercícios não exaustivos, mas que nos foram importantes principalmente por abrangerem as diversas possibilidades que imaginamos aos grupos mais vulneráveis a homicídios. Por sua vez, essas perspectivas foram motivadas pela necessidade de se pensar, o mais breve possível, uma ação política para pessoas que sobrevivem a uma perda de alguém por causa de homicídio.

Se na primeira estimativa, publicada em 2019, usamos os dados do Censo Demográfico de 2010 para calcular o grupo populacional, nesta etapa acrescentamos a PNAD para os anos de 2009, 2011 e 2012; e a PNAD Contínua para o período de

4. 0 crime hediondo de feminicídio, homicídio qualificado contra a mulher por razões de condição de sexo feminino, foi publicado enquanto Lei no 13.104, em agosto de 2015. Disponível em: <http://www.planalto.gov.br/ccivil_03/_ato20152018/2015/lei/L13104.htm>. Acesso em: 24 mar. 2020.

5. A Lei Maria da Penha foi publicada enquanto Lei no 11.340, em agosto de 2006. Disponível em: <http://www.planalto. gov.br/ccivil_03/_ato2004-2006/2006/lei/l11340.htm>. Acesso em: 24 mar. 2020. 
2012 a 2017, assim como mantivemos a estimativa para o Censo Demográfico de 2010. Inicialmente iríamos evitar os anos de 2009 e 2011, para seguir com a comparaçáo da mesma base e metodologia de pesquisa apenas com a PNAD Contínua. Contudo, ao calcularmos ambos grupos populacionais com a PNAD e com a Pnad Contínua em 2012, percebemos as semelhanças no resultado, o que nos permitiu manter as duas bases. ${ }^{6}$ Os grupos populacionais que usamos foram de pessoas que residiam na mesma moradia no ano da pesquisa com um olhar por raça e cor daquele grupo. Nesse sentido, realizamos nove exercícios com diferentes grupos de moradores no mesmo domicílio com: 1) pelo menos uma pessoa da raça e cor negra; 2) a pessoa responsável pelo domicílio se declarou negra; 3) todas as pessoas são negras; 4) um/a jovem de quinze a 29 anos de idade negro/a ou branco/a; $4 \mathrm{a}$ ) um/a jovem de quinze a dezenove anos de idade negro/a ou branco/a; 4b) um/a jovem de vinte a 29 anos de idade negro/a ou branco/a; 5) um/a adolescente de doze a dezoito anos de idade negro/a ou branco/a; 6) onde houvesse pelo menos uma criança, com idade entre zero a onze anos negra ou branca; 7) todas as pessoas são brancas; 8) pelo menos uma pessoa branca; 9) a pessoa responsável se declarou branca (quadro 1).

A classificação das vítimas de homicídios varia de acordo com o grupo populacional a ser estimado. Vamos analisar três tipos de grupos: i) o grupo de pessoas autodeclaradas nas pesquisas domiciliares classificadas como raça/cor negra; ii) o grupo específico de pessoas brancas; e iii) o grupo de pessoas composto pela junçáo entre os dois grupos anteriores, ou seja, pessoas negras e brancas.

Para as situaçôes nas quais o objetivo contemplou estimar os sobreviventes relacionados a crianças (de zero a onze anos), a adolescentes (de doze a dezoito anos) e a jovens (de quinze a 29 anos), ${ }^{7}$ usou-se apenas o conjunto de vítimas de homicídio nos dois grupos populacionais mais afetados diretamente por homicídios no Brasil - logo, as pessoas de raça/cor negras e brancas.

6. Como estamos em fase de elaboração da metodologia, resolvemos testar com a PNAD (2009, anterior ao Censo Demográfico de 2010 e 2011) para ver as possibilidades. Como os resultados não se distanciam dos resultados encontrados na PNAD Contínua, optamos por incorporar a nossa estimativa, ainda que haja diferenças reais que implicam comparações mais assertivas entre as duas bases.

7. Manteremos o intervalo de idade utilizado na primeira estimativa, o Texto para Discussão no 2489, para considerar jovens aqueles/as com idade entre quinze a 29 anos, um costume adotado pela Unicef e também nas pesquisas realizadas no âmbito da Disoc/lpea. 
QUADRO 1

Conjunto de exercícios para a quantificação de sobreviventes

\begin{tabular}{|l|l|c|}
\hline Exercício & \multicolumn{1}{|c|}{ Sobreviventes } & Situação da vítima de homicídio \\
\hline E1 & Reside no domićílio pelo menos uma pessoa que se declarou ou foi declarada negra. & Negra \\
\hline E2 & A pessoa responsável pelo domicílio se declarou negra. & Negra \\
\hline E3 & Todas as pessoas são negras. & Negra \\
\hline E4 & $\begin{array}{l}\text { Reside no domićlio pelo menos um/a jovem de quinze a } 29 \text { anos de idade que se declarou } \\
\text { ou foi declarado/a negro/a ou branco/a. }\end{array}$ & Negra e Branca \\
\hline E4a & $\begin{array}{l}\text { Reside no domićlio pelo menos um/a jovem de quinze a dezenove anos de idade que se } \\
\text { declarou ou foi declarado/a negro/a ou branco/a. }\end{array}$ & Negra e Branca \\
\hline E4b & $\begin{array}{l}\text { Reside no domićlio pelo menos um/a jovem de vinte a 29 anos de idade que se declarou } \\
\text { ou foi declarado/a negro/a ou branco/a. }\end{array}$ & Negra e Branca \\
\hline E5 & $\begin{array}{l}\text { Reside pelo menos um/a adolescente de doze a dezoito anos de idade declarado/a } \\
\text { negro/a ou branco/a. }\end{array}$ & Negra e Branca \\
\hline E7 & Reside pelo menos uma criança de zero a onze anos de idade declarada negra ou branca. & Negra e Branca \\
\hline E8 & Todas as pessoas são brancas. & Branca \\
\hline E9 & Reside pelo menos uma pessoa que se declarou branca no domićlio. & Branca \\
\hline
\end{tabular}

Elaboração das autoras.

Como as informaçóes da quantidade de homicídio são majoritariamente produzidas por UF e por município, nas cidades onde há uma taxa de homicídio que justifique pesquisas específicas - seja pela presença de uma quantidade maior de homicídios, seja pelo aumento e tendência de crescimento da taxa de homicídio -, compomos a estimativa para duas classificaçóes geográficas. Primeiramente, de modo a criar um panorama nacional, organizamos por Brasil e por UF mais Distrito Federal. Em segundo lugar, para nos aproximarmos dos municípios que possuem indicadores de maior quantidade absoluta e também taxa de homicídio, ${ }^{8}$ elaboramos a quantificação por região metropolitana (RM). ${ }^{9}$ Aquela nos permite seguir em consonância aos trabalhos já publicados no Ipea, enquanto esta nos possibilita dialogar com o projeto estabelecido pela Unicef com grupos de pessoas sobreviventes a homicídio de crianças e adolescentes nas localidades de Fortaleza (Ceará), Maceió (Alagoas), Recife (Pernambuco), cidade do Rio de Janeiro

8. Em alguns Textos para Discussão há estudos de casos sobre municípios e UFs específicas como Rio de Janeiro, São Paulo, Espírito Santo (Cerqueira et al., 2020; Cerqueira e Coelho, 2017; Pessoa, 2016; Rodrigues e Rivero, 2012; Cerqueira, 2012; Rodrigues, 2006).

9. As regiões metropolitanas incluídas no projeto Cada Vida Importa da Unicef são: Belém (Pará); Grande São Luís (Maranhão); Fortaleza (Ceará); Recife (Pernambuco); Maceió (Alagoas); Salvador (Bahia); Rio de Janeiro (RJ); e São Paulo (SP). Acrescentamos Brasília (DF), por ser a capital do Brasil e por chamar atenção diante de indicadores próximos aos das Regiões Metropolitanas inclusas no projeto. 
(Rio de Janeiro), Salvador (Bahia), cidade de São Paulo (São Paulo), Brasília (Distrito Federal), Belém (Pará) e São Luís (Maranhão). ${ }^{10}$

Pensando na possibilidade de comparar nossos achados com as pesquisas desenvolvidas no Ipea acerca de homicídios, mantemos a Classificação Internacional de Doenças e Problemas Relacionados à Saúde (CID ${ }^{11}$ utilizada no Atlas da Violência. Vamos incorporar os códigos da CID do Protocolo de Bogotá de modo a enriquecer as possibilidades de pensar a diversidade de cenários de sobreviventes. Mantivemos os códigos da CID presentes na estimativa anterior (Goes e Lopes, 2019), quais sejam CID 10, categorias X85-Y09 e Y35-Y36. ${ }^{12}$

Um segundo grupo da CID é indicado pelo Protocolo de Bogotá, as categorias Y87.1, Y89.0 e Y89.1, ${ }^{13}$ um acréscimo aos códigos já utilizados que fariam ampliação na quantidade de vítimas de homicídios por incluir outros motivos de morte como suicídio. A iniciativa de países da América Latina e Caribe cumpre um acordo entre os Estados para manter a qualidade de dados de homicídios entre as instituiçôes que produzem os dados primários e aquelas que se utilizam das informaçóes. Desse modo, a ideia é uma convergência entre as fontes para integrar e padronizar os dados de modo que possam ser acompanhados e comparados, até a medida do possível.

Considerando os critérios de classificação das famílias, descritos no quadro 1, calculamos o tamanho médio da família típica ${ }^{14}$ com a desagregação geográfica por Brasil, UF e RM.

10. Em Fortaleza, o Projeto Cada Vida Importa, com acordo assinado em 2017 entre Unicef e a prefeitura de Fortaleza, é uma iniciativa para prevenção de homicídios na adolescência. Uma das considerações do projeto foi apontar a aproximação territorial entre as vítimas de homicídio na juventude, inclusive com relações de amizade. Disponível em: <http://cadavidaimporta.com.br/>. Acesso em: 6 abr. 2020.

11. Classificação Estatística Internacional de Doenças e Problemas Relacionados com a Saúde (CID), desenvolvida pela Organização Mundial de Saúde (OMS) com objetivo de acompanhar incidência e ocorrência de doenças com uma metodologia universal.

12. A CID 10, décima edição, está relacionada a lista de causas de morte, da OMS, relacionadas a agressões (X85-Y09); e intervenções legais e operações de guerra (Y35-Y36). Há previsão de adoção da CID 11 a partir de 2022 por todos os Estados-membros.

13. No Protocolo de Bogotá indica-se incluir como causa de morte por homicídio outros códigos na CID 10. Os códigos Y87.1 referente à sequela de uma lesão autoprovocada intencionalmente; Y89.0, sequelas de outras causas externas, sequelas de intervenção legal; e Y89.1, sequelas de operação de guerra.

14. Empregadas/os domésticas/os, parentes de empregadas/os domésticas/os e pensionistas foram excluídos do cálculo. 
A metodologia deste estudo tomou como base Redmon (1989 apud Zinzow, 2009), que conduziu exercício similar nos Estados Unidos, concluindo que para cada homicídio havia entre sete a dez familiares próximos afetados diretamente, desconsiderando amigos, vizinhos e colegas de trabalho, sem recorte por raça/cor. No caso do Brasil, a partir dos dados da PNAD (2009, 2011 e 2012) e PNAD Contínua (2012-2017), ${ }^{15}$ o cálculo do número médio de moradores por domicílio seguiu a expressão:

$$
\bar{x}_{j}=\frac{1}{n} \sum_{i=1}^{n} x_{i j}=\frac{1}{n}\left(x_{1 j}+\cdots+x_{n j}\right),
$$

em que $x_{i}$ é a quantidade de moradores no domicílio $i$ que atende uma determinada característica dentro de cada exercício, $j$ representa o recorte espacial (Brasil, UFs e RMs) e $n$ o número de domicílios com essa característica.

Por exemplo, no E1, a característica necessária é que exista no domicílio pelo menos um/a morador/a classificado/a como negro/a. Assim, no E2 considera-se a média de moradores em domicílios chefiados por negros/as; e, no E3, a média de moradores em domicílios com jovens de quinze a 29 anos. Nos demais exercícios, a característica necessária varia de acordo com a medida almejada.

Portanto, $\bar{x}$ é o multiplicador, isto é, o fator de mensuração da extensão das prováveis vítimas indiretas dos homicídios. Dito isso, o número total de vítimas indiretas é medido com a fórmula:

$$
\text { Vítimas }_{j}=\text { Homicídios }_{i j}\left(\bar{x}_{j}-1\right) \text {, }
$$

em que Homicídios ${ }_{i j}$ representa o total de homicídios obtidos por meio dos microdados do SIM/Departamento de Informática do Sistema Único de Saúde (Datasus), com $i$ refletindo a faixa etária das vítimas, ora jovens inclusive, ora jovens exclusive; e $j$ é a dimensão espacial em análise. Ao multiplicador, devem-se excluir as vítimas diretas

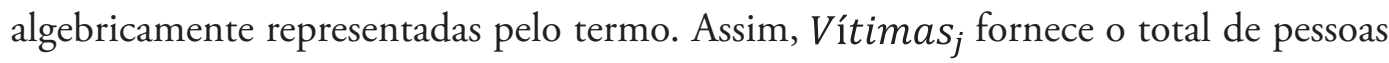
que foram vítimas sobreviventes de homicídios por recorte geográfico $j$.

15. Observamos que o número médio de moradores por município da PNAD não foi afetado pela mudança de metodologia da PNAD Contínua, portanto mantivemos a série histórica 2009-2017.

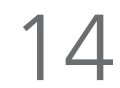




\subsection{0 uso da mesma metodologia de estimativa com dados da PNAD e da PNAD Contínua em anos diferentes}

Destarte não ser recomendado a comparação entre PNAD e PNAD Contínua, ao calcularmos o multiplicador para 2012 tanto pela PNAD quanto pela PNAD Contínua em todos os exercícios da estimativa, percebemos uma aproximação entre os valores para o ano de 2012. Desse modo, incluímos a possibilidade de inserir os anos de 2009 e 2011 com os dados da PNAD, para nos ajudar a criar uma noção no processo temporal. Para tanto, optamos por manter o ano de 2012 nas tabelas com resultados calculados tanto com a PNAD, quanto com a PNAD contínua.

Observando os casos para o Brasil, a menor variaçáo do multiplicador entre os resultados com a PNAD e com a PNAD contínua para o ano base de 2012 foi de $0,5 \%$, no E5 - ou seja, para o caso de um homicídio de uma pessoa branca em um domicílio que resida pelo menos um adolescente com doze a dezoito anos de idade branco. Enquanto a maior variação foi de $3,1 \%$, para a situação E7, homicídio de uma pessoa branca em que todas as pessoas no domicílio são brancas. Já para o resultado de sobreviventes, a maior variaçáo também foi encontrada no E7, de 23.871 a 25.079 o que representa $4,8 \%$; e a menor no E5, de 4.583 a 4.613, representando $0,6 \%$ (tabela 1 ).

No conjunto de exercícios relacionados à população negra, em que havia pelo menos uma pessoa negra no domicílio, o multiplicador foi de 3,34 para PNAD e de 3,40 para a PNAD contínua, com total de sobreviventes de 90.042 e de 92.202 , respectivamente. Para homicídios contra a população negra no qual o responsável pelo domicílio se declarou negro, o multiplicador variou de 3,27 e de 3,32, com 87.293 e 89.261 sobreviventes. Na situação em que todas as pessoas no domicílio são negras, a variação foi quase inexistente, de 3,00 para 3,09, com sobreviventes entre 77.079 e 80.604 .

Nos exercícios direcionados a analisar a estimativa de sobreviventes relacionada às idades mais vulneráveis a homicídios como jovens, adolescentes e crianças - seja branco, seja negro -, as variações entre PNAD e PNAD Contínua não alteram a manutenção da metodologia com as duas bases de dados. Para a juventude, pessoas de quinze a 29 anos de idade, o multiplicador altera de 3,67 a 3,71 para brancos, e de 3,94 a 4,01 para negros. A quantidade de sobreviventes vai de 17.779 a 18.033 para brancos, e de 64.136 a 65.505 para negros. Ao desagregar as idades de quinze a dezenove anos, o multiplicador altera de 4,10 a 4,14 para brancos, e de 4,44 a 4,51 para negros. Os sobreviventes vão de 5.678 a 5.736 
para brancos, e de 23.190 a 23.699 para negros. No intervalo de vinte a 29 anos de idade, a variação do multiplicador vai de 3,56 a 3,61 para brancos, e de 3,87 a 3,93 para negros. A quantidade de sobreviventes de 12.370 a 12.598 para brancos, e de 43.159 a 44.063 para negros. Para crianças com zero a onze anos de idade, o multiplicador sai de 4,14 a 4,17 para brancos, e de 4,44 a 4,48 para negros. A quantidade de sobreviventes vai de 387 a 390 para brancos, e de 749 a 758 para negros. Aos adolescentes brancos, de doze a dezoito anos de idade, o multiplicador varia de 4,15 a 4,17, e os sobreviventes de 4.583 a 4.613. Para os adolescentes negros, a variação vai de 4,45 a 4,51, e os sobreviventes de 18.967 a 19.285.

No conjunto de estimativas para pessoas brancas, em que todas as pessoas no domicílio são brancas, o multiplicador vai de 2,65 a 2,74, e os sobreviventes de 23.871 a 25.079. Nas pessoas que residem no mesmo domicílio em que pelo menos uma pessoa é branca, o multiplicador sai de 3,15 a 3,19, e os sobreviventes de 31.005 a 31.537. Quando o responsável pelo domicílio é branco, a variação do multiplicador vai de 2,92 a 2,97, e os sobreviventes de 27.637 a 28.452. Portanto, as tabelas com os resultados dos exercícios de estimativas a sobreviventes de homicídios no Brasil se iniciam em 2009 e vão até 2017, com o uso das duas bases de dados de pesquisas domiciliares, PNAD e PNAD Contínua.

TABELA 1

Variação do multiplicador e do total de sobreviventes entre PNAD e PNAD Contínua (2012)

(Em \%)

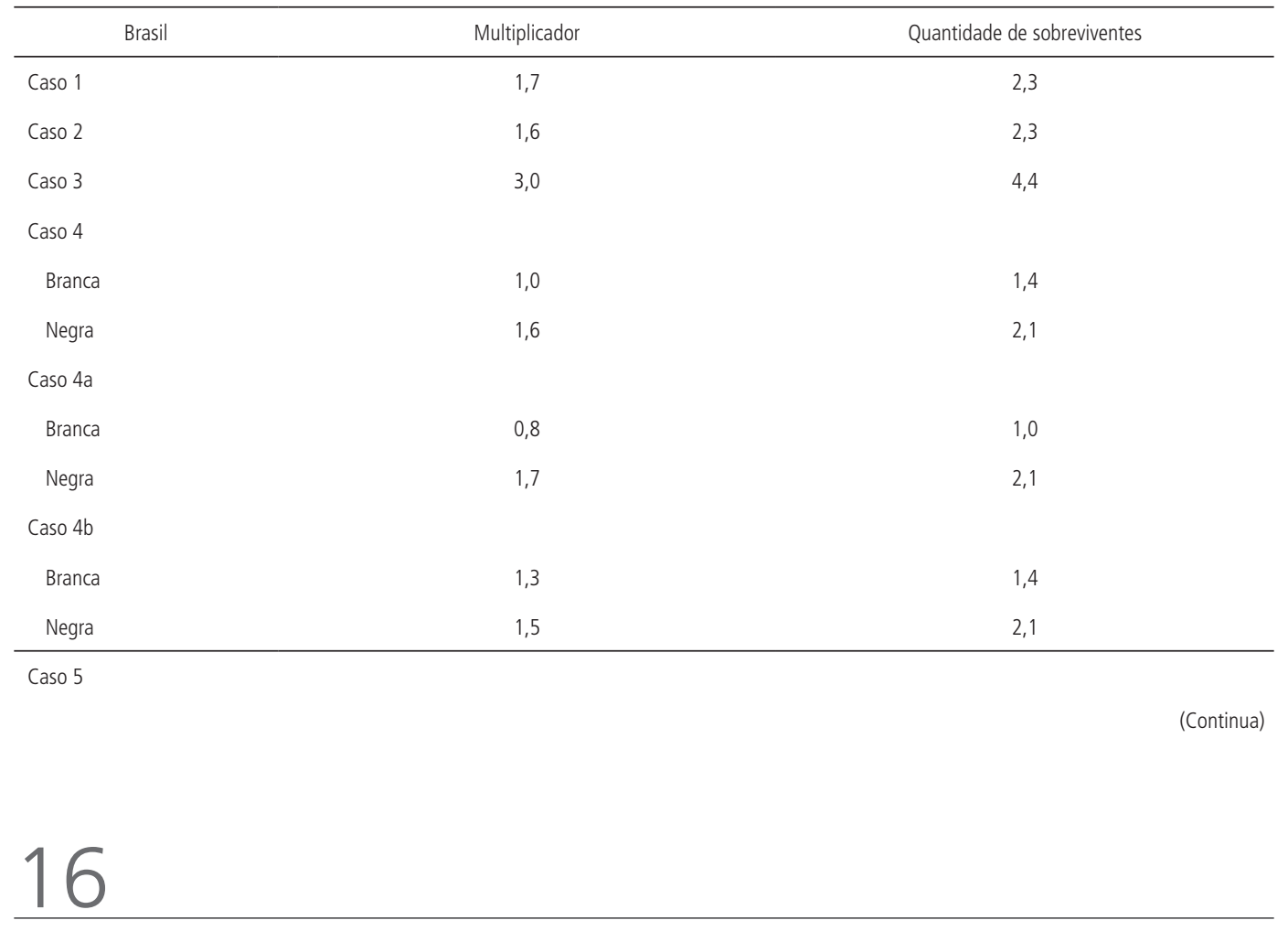




\begin{tabular}{ccc} 
(Continuação) & & \\
\hline \multicolumn{1}{c}{ Brasil } & Multiplicador & Quantidade de sobreviventes \\
\hline Branca & 0,5 & 0,6 \\
Negra & 1,3 & 1,6 \\
Caso 6 & & \\
Branca & 0,6 & 0,8 \\
Negra & 1,0 & 1,3 \\
Caso 7 & 3,1 & 4,8 \\
Caso 8 & 1,2 & 1,7 \\
Caso 9 & 1,9 & 2,9 \\
\hline
\end{tabular}

Elaboração das autoras.

\subsection{Razão de chances para comparação entre brancos e negros}

A fim de investigar se o comportamento da taxa de homicídios contra pessoas negras realmente é acima daqueles contra pessoas brancas, como esperado, utilizamos a razáo de chances (odds ratio), que será melhor abordado na seção 3.2.

\section{RESULTADOS BASEADOS EM INFORMAÇÕES DE PESQUISAS DOMICILIARES E REFERENTES A HOMICÍDIOS NO BRASIL}

\subsection{Sobreviventes a homicídios no Brasil}

A análise dos resultados da estimativa está organizada a seguir, em três grupos, tanto para as UFs quanto para as RMs: i) aos sobreviventes negros atingidos por homicídio de uma pessoa negra; ii) aos grupos de jovens, adolescentes e crianças, negros e brancos; e iii) aos sobreviventes brancos impactados por homicídio de uma pessoa branca. Para as RMs o período disponibilizado será de 2012 a 2017, visto que a PNAD Contínua iniciada em 2012 começa a agregar as informaçóes por RM.

Nos três primeiros exercícios, estimam-se os sobreviventes de homicídio contra a população negra. No E1, calculam-se os sobreviventes em que há pelo menos uma pessoa negra na família. A Bahia foi a UF com maior quantidade de sobreviventes, com aproximadamente 12 mil pessoas em 2009, chegando a quase 14 mil em 2017. Para o total nacional, sobreviveram 84 mil pessoas negras, e em 2017 foram quase 106 mil. 
No exercício onde o responsável pelo domicílio é negro, há uma menor variação quando comparamos os exercícios E1 e E2. Portanto, podemos nos basear principalmente em E1, uma vez que, ao observarmos apenas os sobreviventes no âmbito do domicílio, estamos calculando um valor inferior à quantidade real de pessoas indiretamente impactadas por homicídios. Ou seja, podemos usar os valores maiores que, ainda assim, estaremos sub quantificando a estimativa. A mesma situação poderá ser encontrada nos casos E8 e E9, nos quais calculamos os sobreviventes de homicídio para população branca em que há pelo menos uma pessoa branca e o responsável pelo domicílio é branco.

Entretanto, ao observarmos a perspectiva racial dos sobreviventes percebemos dois aspectos que podem colaborar na identificação de grupos de sobreviventes. $\mathrm{O}$ primeiro consiste na quantidade de sobreviventes brancos, que é inferior à de negros, em 2009 eram 34 mil e, em 2017, quase 29 mil sobreviventes brancos. A segunda característica é a reprodução da tendência de diminuição de homicídios entre a população branca e, no caso específico, a tendência à diminuição de sobreviventes relacionados aos homicídios perpetrados contra a população branca. Por um lado, há o aumento da quantidade de pessoas impactadas por homicídios contra negros e negras; por outro lado, as pessoas brancas vão sendo menos atingidas.

Os multiplicadores para os grupos de pessoas negras são maiores se comparados aos grupos de pessoas brancas nos casos E1, E2, E3 e E7, E8 e E9. Mais uma vez, reflete-se a realidade brasileira, em que há menor densidade populacional nas residências com maior presença de pessoas brancas. A semelhança é a tendência de diminuição do multiplicador, exatamente em função da tendência à diminuição per capita nos domicílios. Para o Brasil, em 2009, no caso em que todas as pessoas residentes no domicílio eram da mesma raça/ cor que as vítimas, havia um multiplicador de 2,79 para brancos e 3,13 para negros; enquanto, em 2017, os multiplicadores diminuíram para 2,61 e 2,89, respectivamente.

Quando o responsável pelo domicílio é branco (E9), a quantidade de sobreviventes no Brasil foi de 30 mil pessoas, em 2009, para 26 mil, em 2017. No E8, com pelo menos uma pessoa branca na família, o total foi de 34 mil, em 2009, para 29 mil, em 2017. Portanto podemos concluir que em 2009 havia, no mínimo, 34 mil pessoas brancas impactadas por homicídios contra pessoas brancas e 84 mil pessoas negras impactadas por homicídios contra pessoas negras. Em 2017, os sobreviventes foram 29 mil e 105 mil, para brancos e negros, respectivamente. Não seria de todo errado afirmar que, 
grosso modo, as pessoas que residem em domicílios com pelo menos uma pessoa negra tem maior possibilidade de ser vítima indireta de homicídio. Principalmente as pessoas negras, mas também as pessoas brancas residentes em domicílios com pessoas negras, pois não excluímos as pessoas brancas no cálculo em que há pelo menos uma pessoa negra no domicílio onde residiu uma vítima negra de homicídio.

A juventude negra é a principal vítima de homicídios no Brasil. Nas últimas duas décadas, a concentração de mortes por homicídio em jovens negros já despertou a produção de diversas pesquisas e uma quantidade de artigos e livros. Entretanto, ainda que gestores públicos dos municípios, estados e mesmo do governo federal tenham executado algumas iniciativas, ${ }^{16}$ os jovens negros ainda permanecem mais propensos a serem vítimas de homicídio que os jovens brancos.

Por essa razão, elaboramos um recorte para as pessoas de quinze a 29 anos de idade. No Brasil, em 2009, para cada uma pessoa que sobreviveu aos homicídios de um jovem branco, três sobreviveram ao homicídio de um jovem negro. Em 2017, para cada pessoa impactada pela morte de um jovem branco, cinco pessoas sobreviveram aos homicídios de jovens negros. Pode-se afirmar que é conhecimento do senso comum que, no Brasil, jovens negros são mortos em maior quantidade que jovens brancos, o que explicita o racismo estrutural no direito à vida. A morte de um jovem negro não encerra a vida na perspectiva física das pessoas que o conheciam; ao contrário, opera um fator que potencializa as agruras vividas pelas populaçóes negras com a perda de uma - melhor dizendo, mais uma - vida negra. No Brasil, entre 2009 a 2017, pelo menos $600 \mathrm{mil}$ pessoas sobreviveram aos homicídios de jovens negros (gráfico 2), enquanto $160 \mathrm{mil}$ sobreviveram ao homicídio de jovens brancos (gráfico 1). Afirmamos então que, entre os anos de 2009 a 2017, no mínimo 760 mil pessoas foram diretamente afetadas pelo assassinato de um jovem que residia no mesmo domicílio.

16. Movimentos sociais e organismos internacionais também se engajaram contra o aumento de homicídios de jovens negros, como a campanha Vidas Negras Importam. 
GRÁFICO 1

Sobreviventes de homicídio contra a população branca de quinze a 29 anos de idade, por Unidade Federativa'

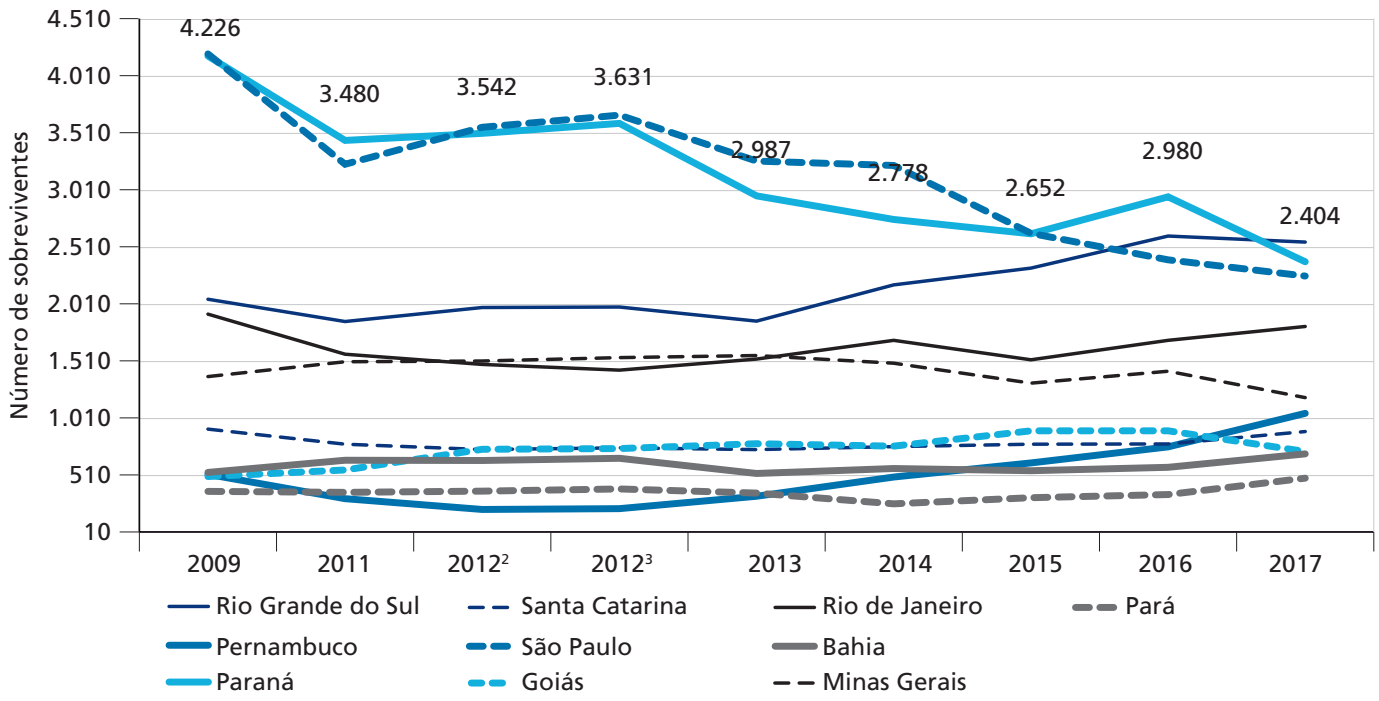

Elaboração das autoras.

Notas: ${ }^{1}$ Apenas as dez UFs que tiveram a maior quantidade de sobreviventes em 2017.

2 Referente à pesquisa PNAD (2012).

${ }^{3}$ Referente à pesquisa PNAD Contínua (2012).

GRÁFICO 2

Sobreviventes de homicídio contra a população negra de quinze a 29 anos de idade, por Unidade Federativa ${ }^{1}$

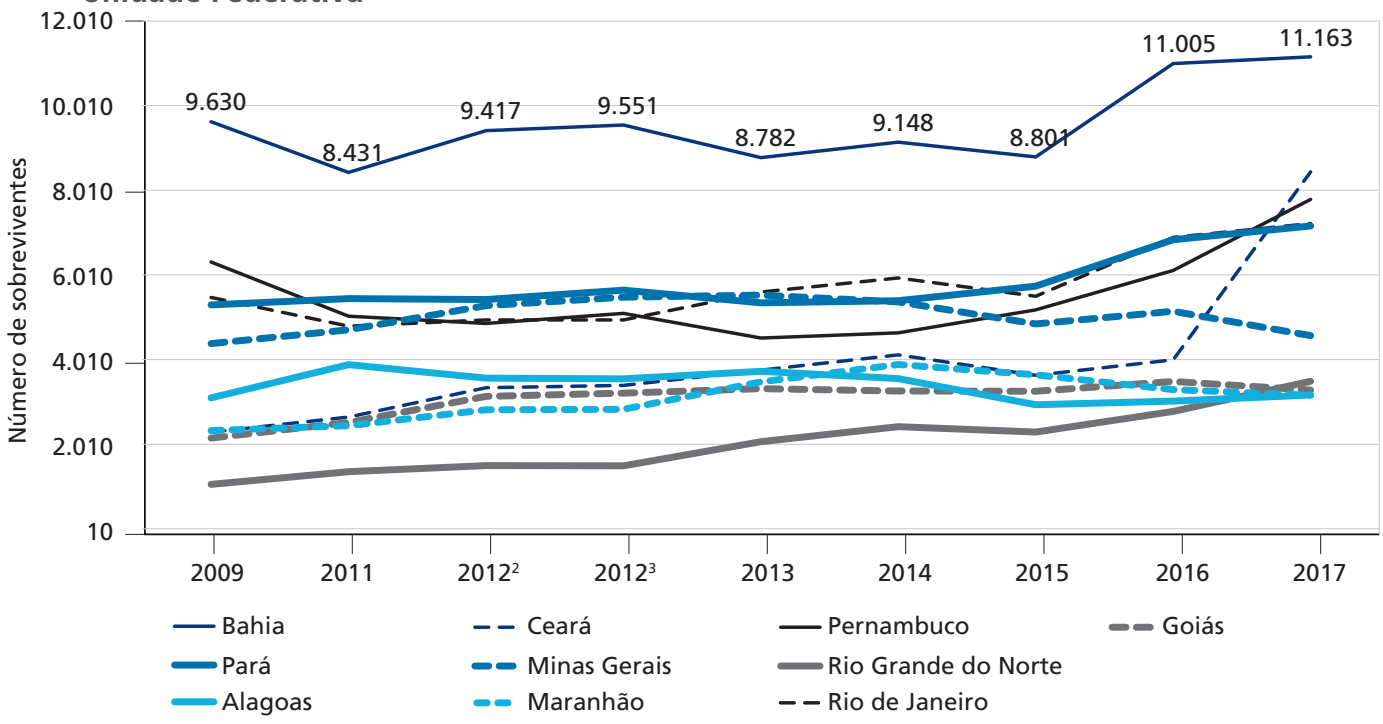

Elaboração das autoras.

Notas: ${ }^{1}$ Apenas as dez UFs que tiveram a maior quantidade de sobreviventes em 2017.

2 Referente à pesquisa PNAD (2012).

${ }^{3}$ Referente à pesquisa PNAD Contínua (2012) 
Nas RMs, para os sobreviventes de homicídios perpetrados contra jovens brancos (quinze a 29 anos de idade), apesar de Sáo Paulo iniciar, em 2009, com maior quantidade de sobreviventes em relação a outras RMs, o município apresenta uma tendência à diminuição. As RMs de Recife e São Luís, mostram aumentos contínuos (gráfico 3). A relação para jovens negros no mesmo intervalo de idade, na RM do Rio de Janeiro, a linha é crescente e há uma acentuada subida de 2016 para 2017 para a RM de Fortaleza (gráfico 4).

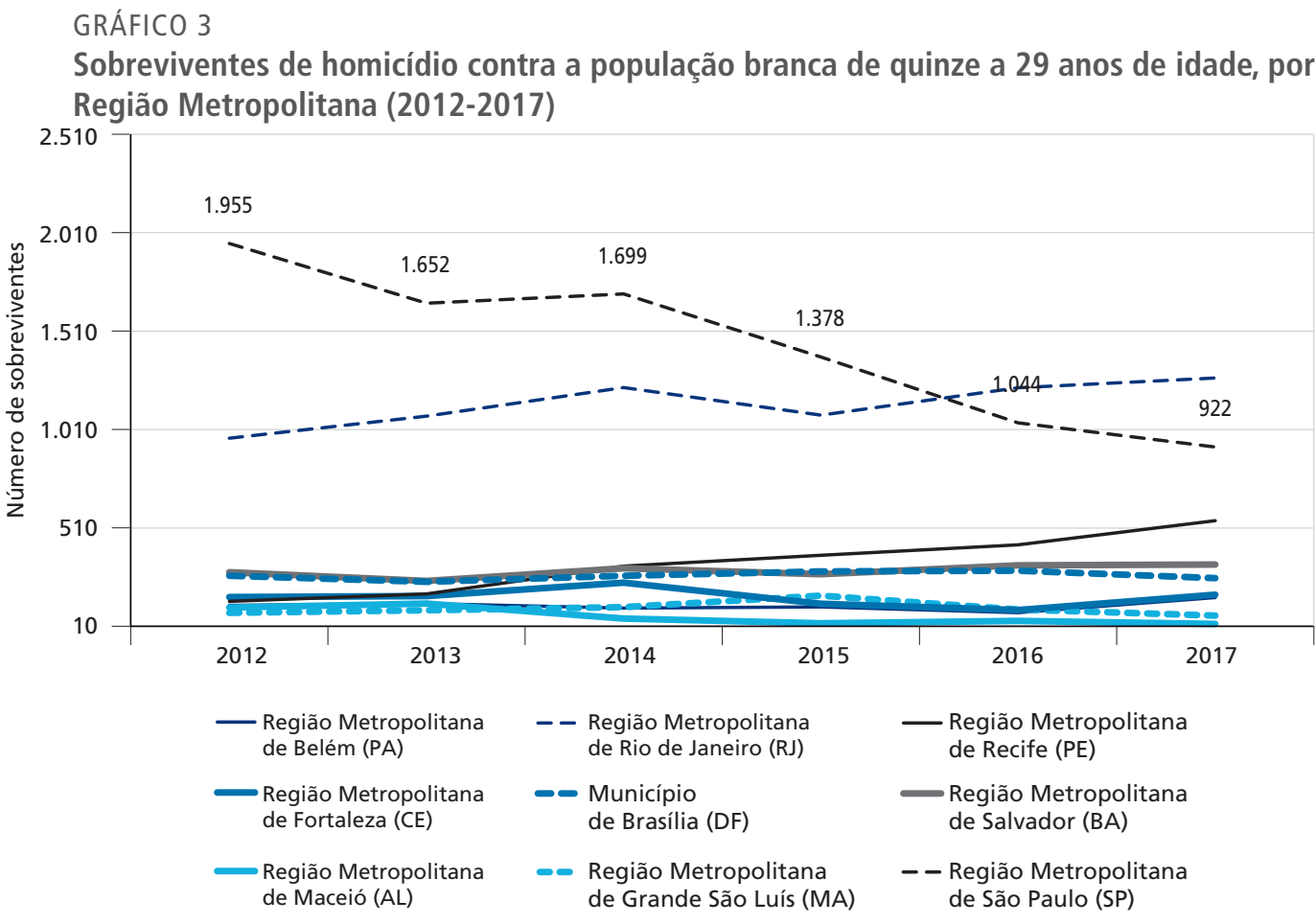

Elaboração das autoras. 


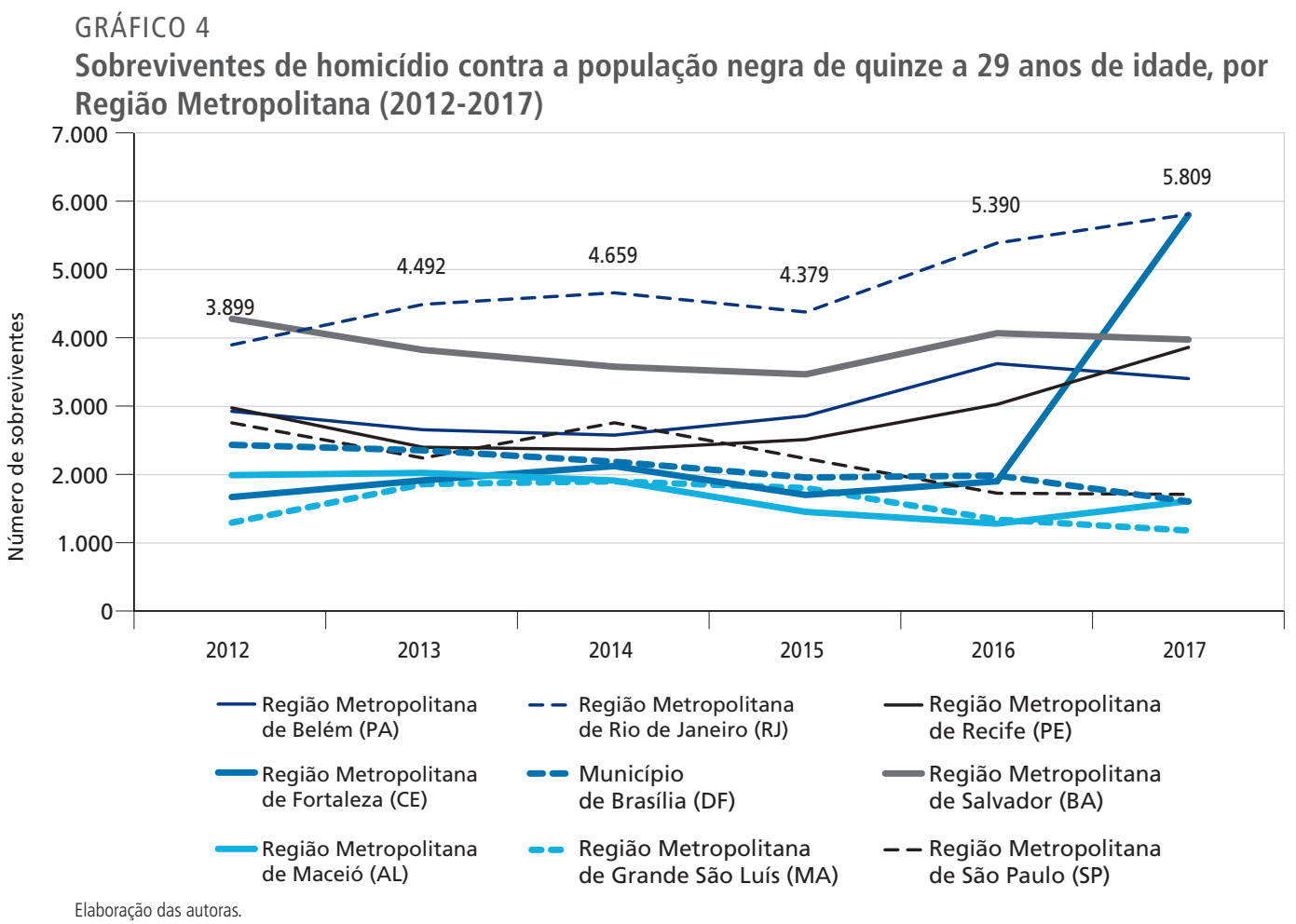

Ao desagregar a juventude negra em dois grupos - um com idade entre quinze a dezenove anos, e o outro entre vinte e 29 anos -, há duas constataçóes a serem apresentadas por cada intervalo de idade. A primeira delas, no intervalo de quinze a dezenove anos de idade, consiste no aumento de aproximadamente 50\% de sobreviventes de 2009 para 2017. Inicialmente, poderia aparentar uma informação distante da realidade ao ver o Paraná com maior quantidade de sobreviventes nesta faixa etária dos quinze aos dezenove anos de idade em 2009, com tendência à diminuição, mas ainda assim mantém-se entre as UFs com maior quantidade de pessoas impactadas por homicídios de jovens nesta idade. Porém, ao observar a raça/cor do grupo, branca, os dados mantém coerência, pois há maior percentual populacional de pessoas brancas nessa UF (gráfico 5). Ao comparar com os dados das RMs, Sáo Paulo ocupa a linha com maior quantidade de sobreviventes brancos no período de 2012 a 2017, para jovens entre quinze e dezenove anos de idade (gráfico 7). Os sobreviventes a homicídios de jovens negros na mesma faixa etária estão mais concentrados na Bahia (gráfico 6); mas, quando se observam as RMs, enquanto a Bahia recua, Belém aumenta a quantidade (gráfico 8). 


\section{GRÁFICO 5}

Sobreviventes de homicídio contra a população branca de quinze a dezenove anos de idade, por Unidade Federativa'

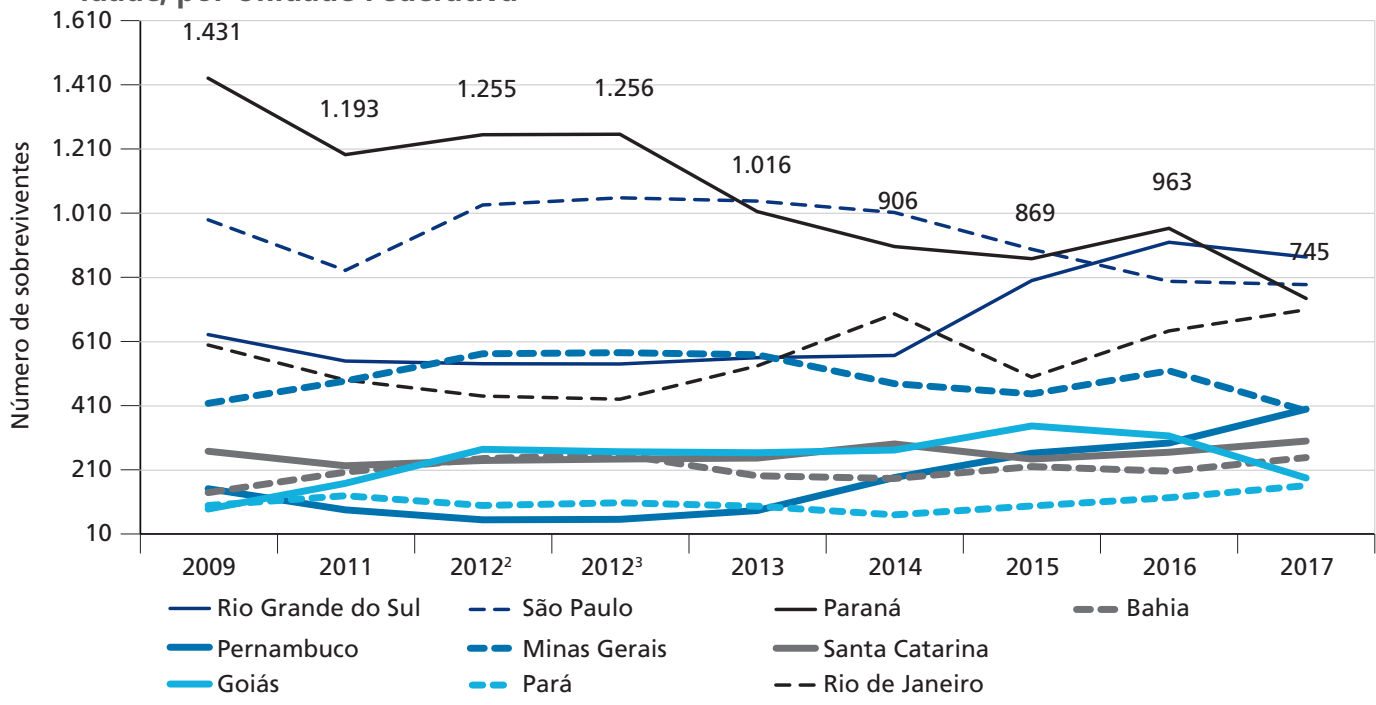

Elaboração das autoras.

Notas: ' Apenas as dez UFs que tiveram a maior quantidade de sobreviventes em 2017.

2 Referente à pesquisa PNAD (2012).

${ }^{3}$ Referente à pesquisa PNAD Contínua (2012).

\section{GRÁFICO 6}

Sobreviventes de homicídio contra a população negra de quinze a dezenove anos de idade, por Unidade Federativa'

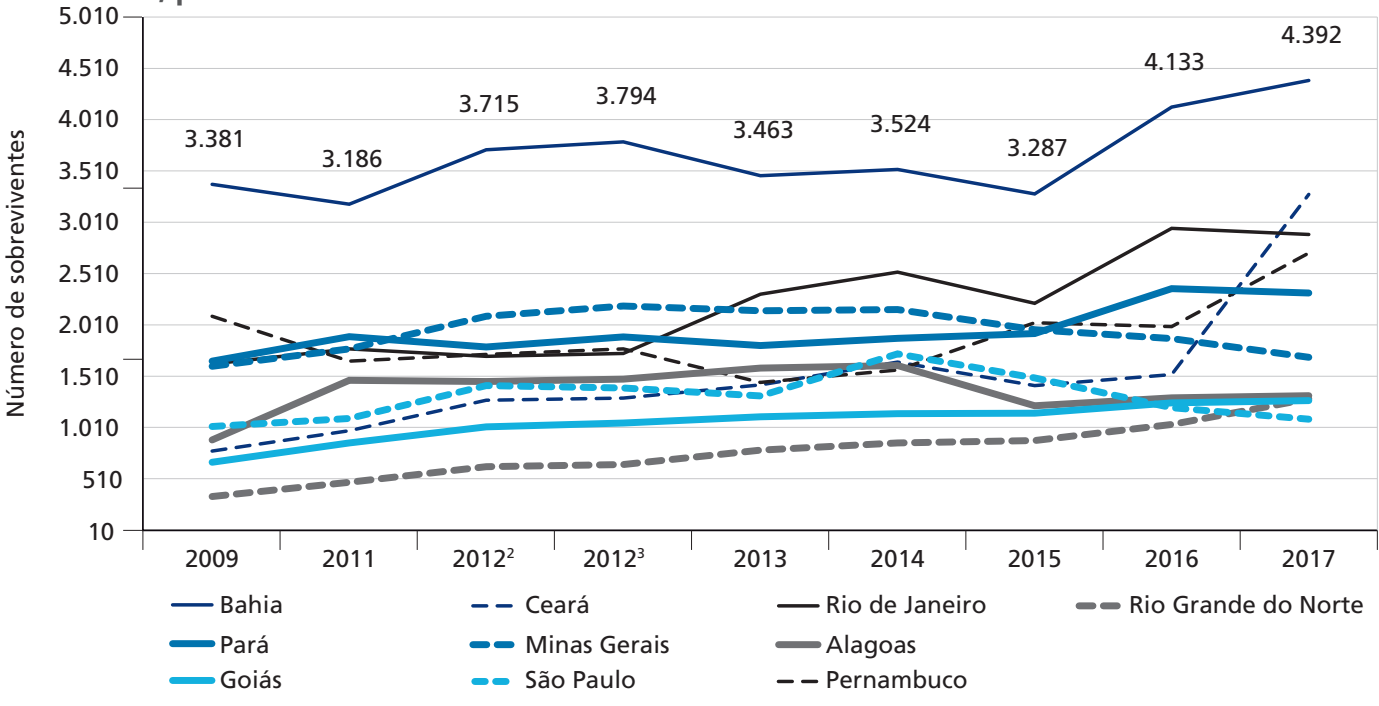

Elaboração das autoras.

Notas: ${ }^{1}$ Apenas as dez UFs que tiveram a maior quantidade de sobreviventes em 2017.

2 Referente à pesquisa PNAD (2012)

${ }^{3}$ Referente à pesquisa PNAD Contínua (2012) 
GRÁFICO 7

Sobreviventes de homicídio contra a população branca de quinze a dezenove anos de idade, por Região Metropolitana (2012-2017)

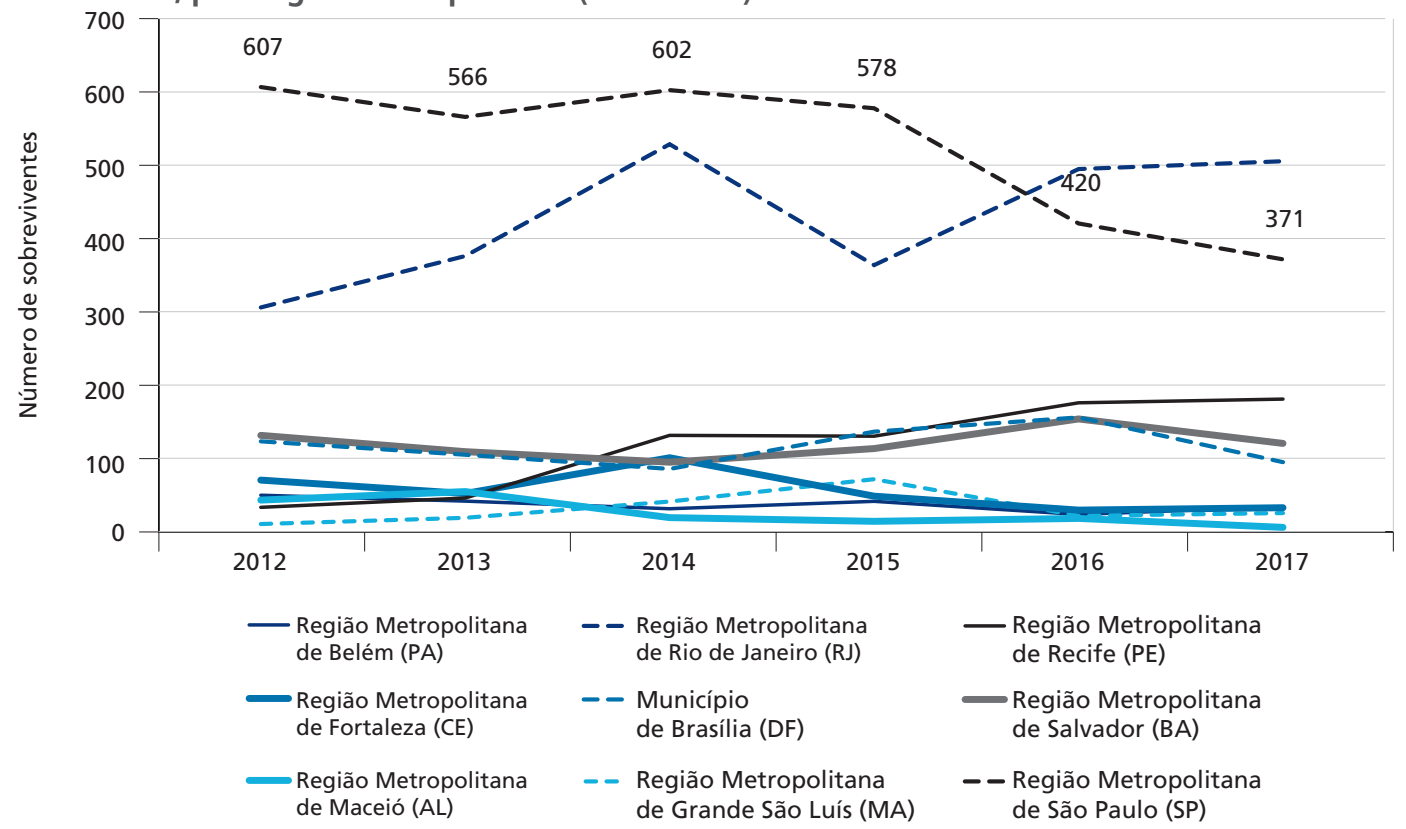

Elaboração das autoras. 


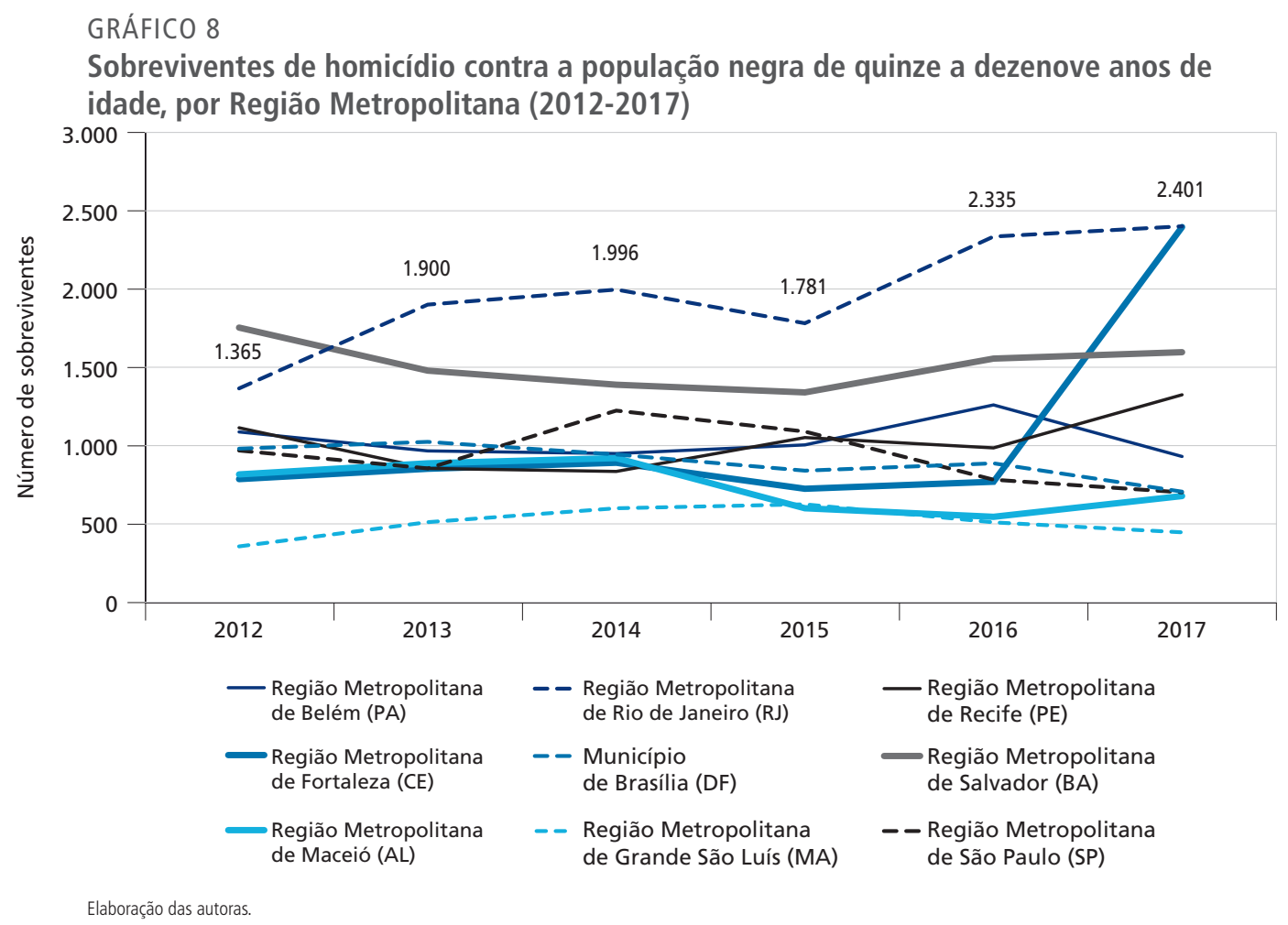

A segunda constatação, no intervalo de vinte a 29 anos de idade, há maior quantidade em números absolutos de sobreviventes nas mortes de jovens negros. Os sobreviventes de homicídios de jovens negros de quinze a dezenove anos de idade, foram aproximadamente 20 mil, em 2009, e 30 mil, em 2017. Para jovens negros de vinte a 29 anos de idade, os sobreviventes, em 2009, foram 42 mil, enquanto, em 2017, foram 52 mil. A diferença também é encontrada no grupo racial branco ainda que no mesmo intervalo de idade. De algum modo, a UF da Bahia concorre com Paraná, haja vista variação étnico-racial das populaçôes de cada estado (gráfico 9). Apesar de alguns momentos de diminuição, a Bahia mantém a maior quantidade de sobreviventes para o período e para o intervalo de idade (gráfico 10). Quando observadas as RMs para as mesmas idades, São Paulo (gráfico 11) e Rio de Janeiro (gráfico 12) indicam maiores quantidades de sobreviventes. 
GRÁFICO 9

Sobreviventes de homicídio contra a população branca de vinte a 29 anos de idade, por Unidade Federativa'

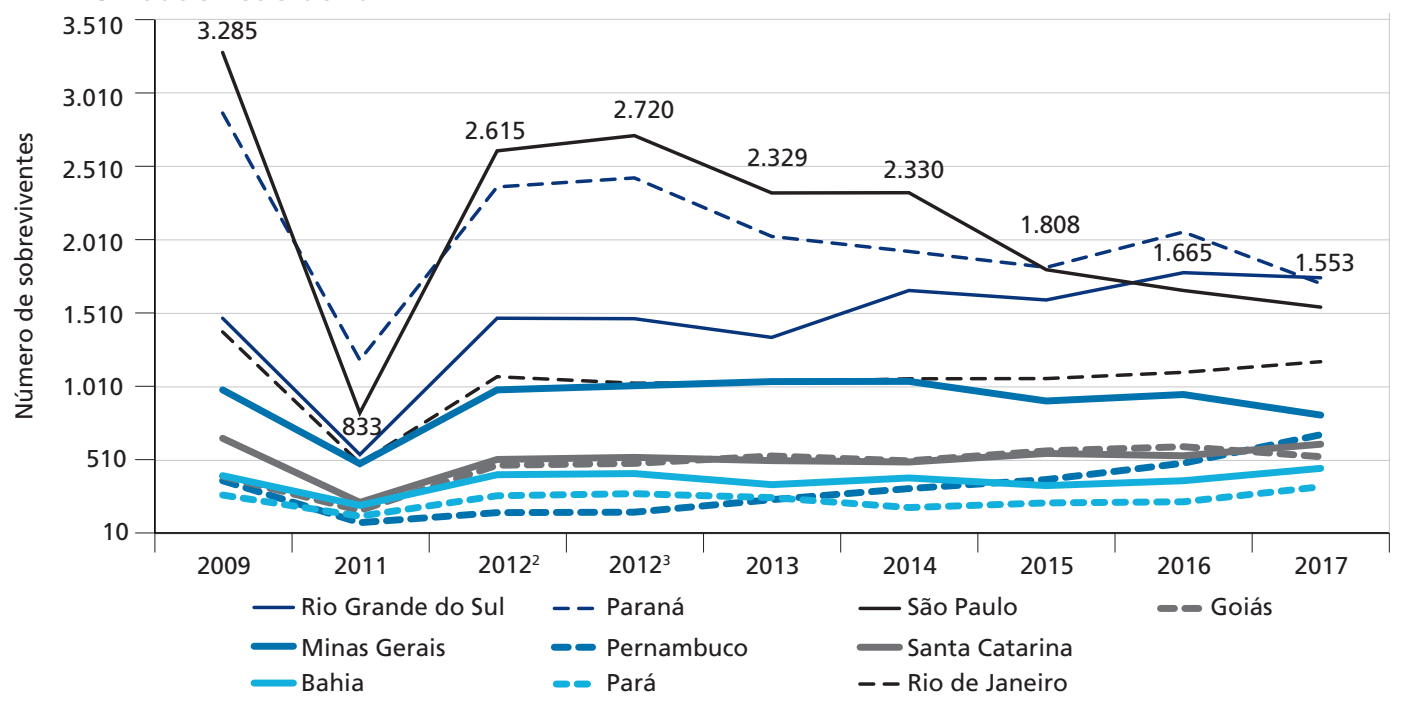

Elaboração das autoras.

Notas: ${ }^{1}$ Apenas as dez UFs que tiveram a maior quantidade de sobreviventes em 2017.

2 Referente à pesquisa PNAD (2012).

${ }^{3}$ Referente à pesquisa PNAD Contínua (2012)

\section{GRÁFICO 10}

Sobreviventes de homicídio contra a população negra de vinte a 29 anos de idade, por Unidade Federativa ${ }^{1}$

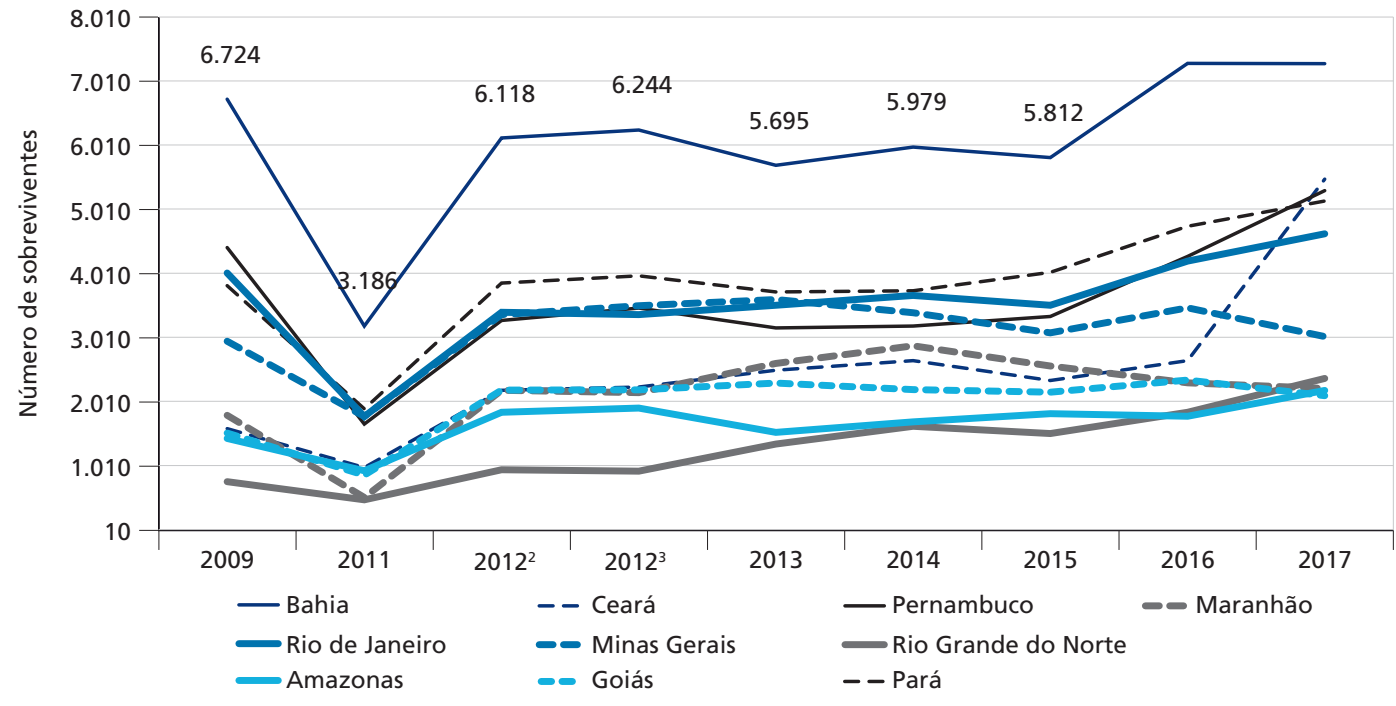

Elaboração das autoras.

Notas: ${ }^{1}$ Apenas as dez UFs que tiveram a maior quantidade de sobreviventes em 2017.

2 Referente à pesquisa PNAD (2012)

${ }^{3}$ Referente à pesquisa PNAD Contínua (2012) 
GRÁFICO 11

Sobreviventes de homicídio contra a população branca de vinte a 29 anos de idade, por Região Metropolitana (2012-2017)

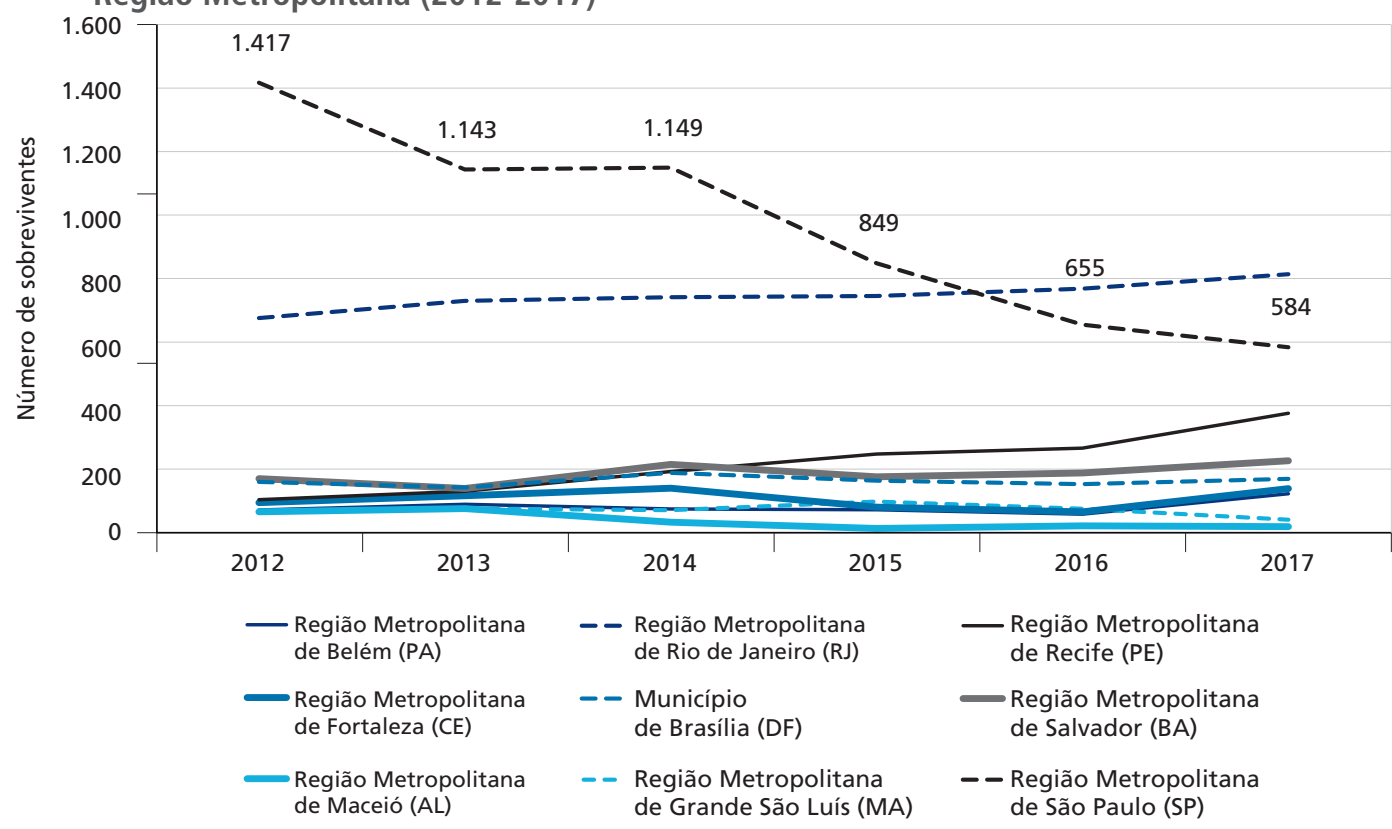

Elaboração das autoras.

\section{GRÁFICO 12}

Sobreviventes de homicídio contra a população negra de vinte a 29 anos de idade, por Região Metropolitana (2012-2017)

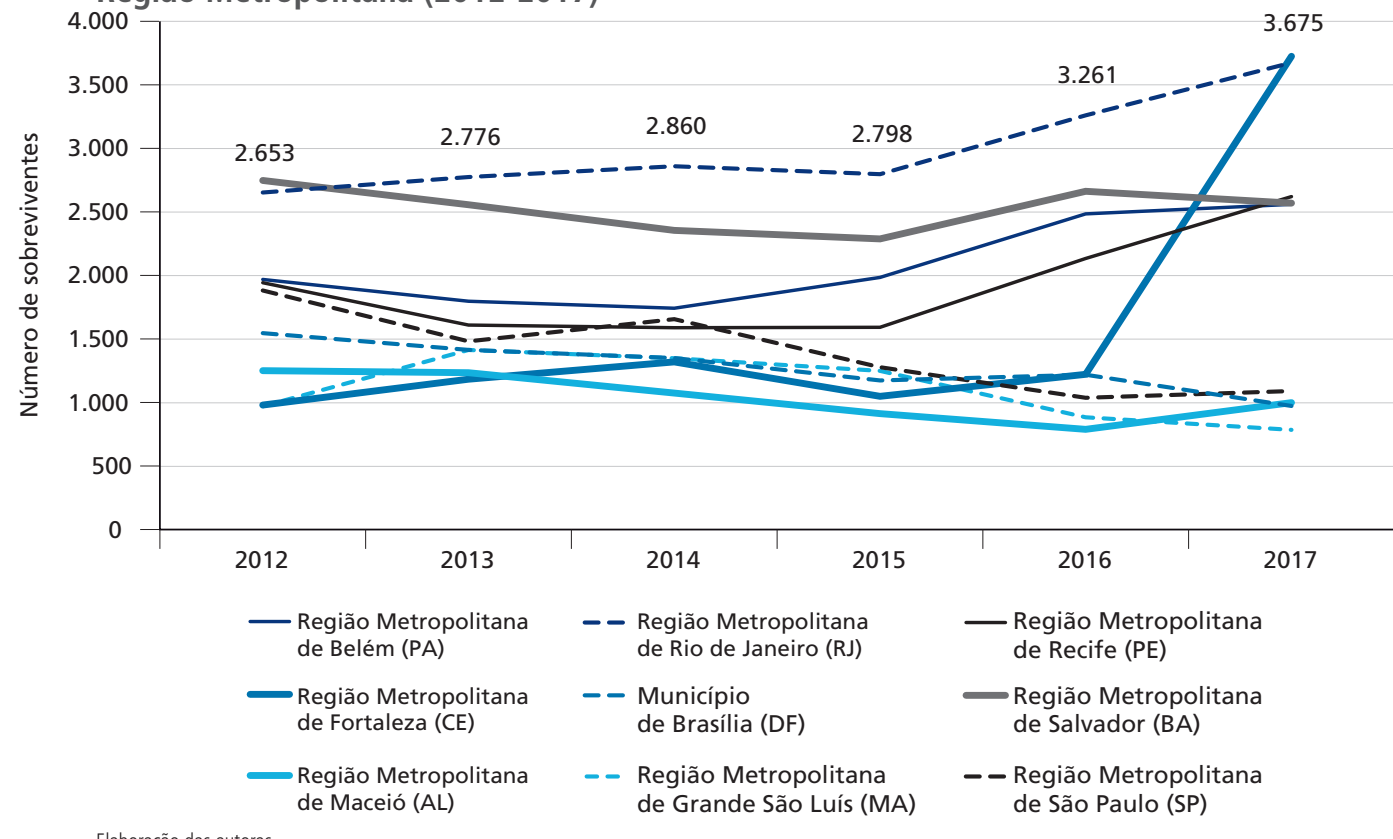

Elaboração das autoras. 
Se a quantidade de sobreviventes afetados por homicídios de adolescentes negros entre doze e dezoito anos de idade segue uma linha crescente de 15.640 (2009) para 23.265 (2017), o movimento para sobreviventes relacionados a adolescentes brancos é de constante variação. Há aumento entre 2011 e 2014, e diminuição entre 2015 e 2017. Porém os valores não variam muito, de 4.316, em 2009, para 4.480, em 2017. Para os jovens adolescentes brancos, o risco é o Paraná (gráfico 13), ao passo que a Bahia é o estado com maior quantidade absoluta de sobreviventes a homicídios de adolescentes negros, com 3.518, em 2017 (gráfico 14). Apesar da tendência de diminuição dos homicídios contra adolescentes brancos, no intervalo de doze a dezoito anos de idade, na RM do Rio de Janeiro, estima-se que houve um aumento de sobreviventes (gráfico 15). A situação mais explícita de aumento na quantidade de sobreviventes aos homicídios contra os adolescentes negros aconteceu na região metropolitana de Fortaleza, entre os anos de 2016 e 2017 (gráfico 16).

GRÁFICO 13

Sobreviventes de homicídio contra a população branca de doze a dezoito anos de idade, por Unidade Federativa'

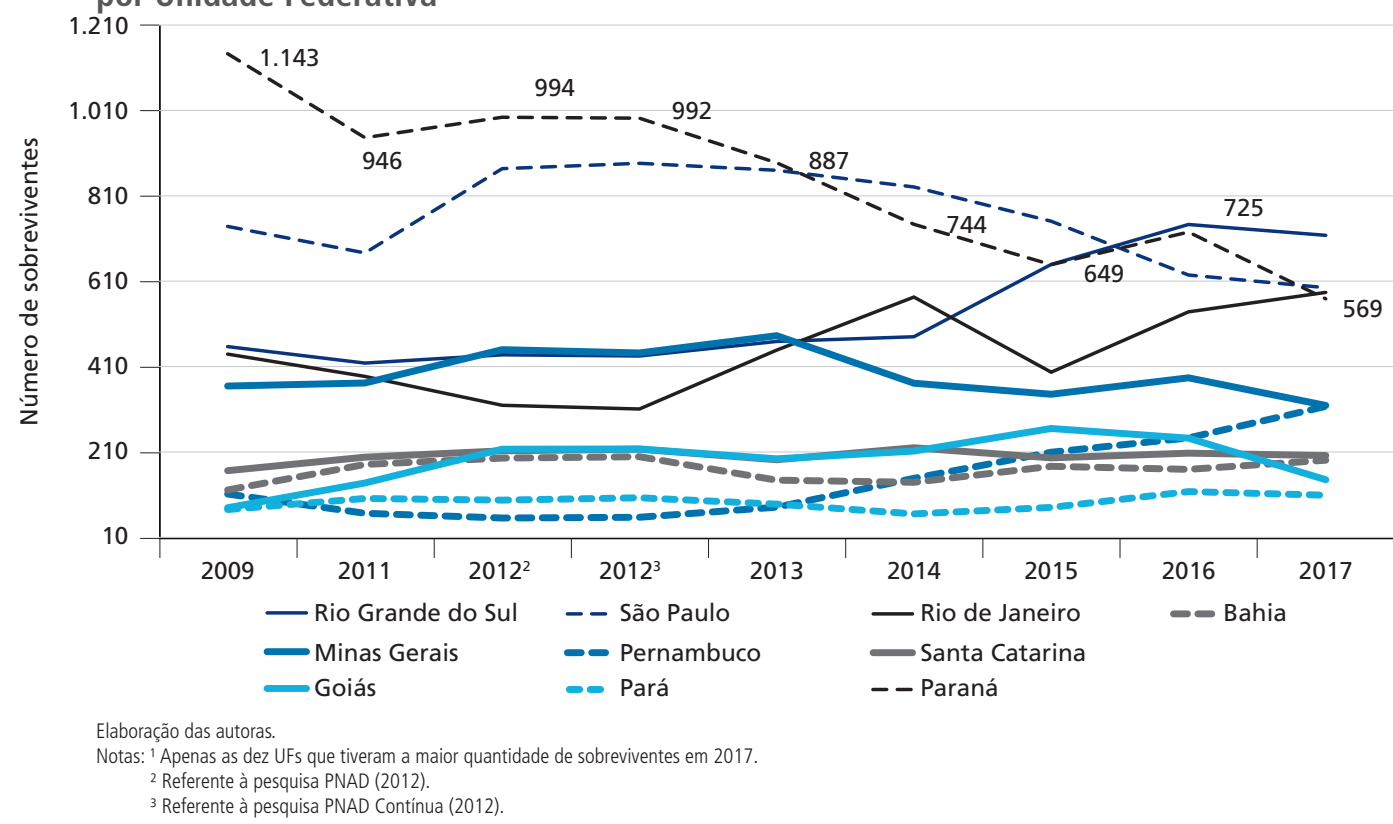


GRÁFICO 14

Sobreviventes de homicídio contra a população negra de doze a dezoito anos de idade, por Unidade Federativa ${ }^{1}$

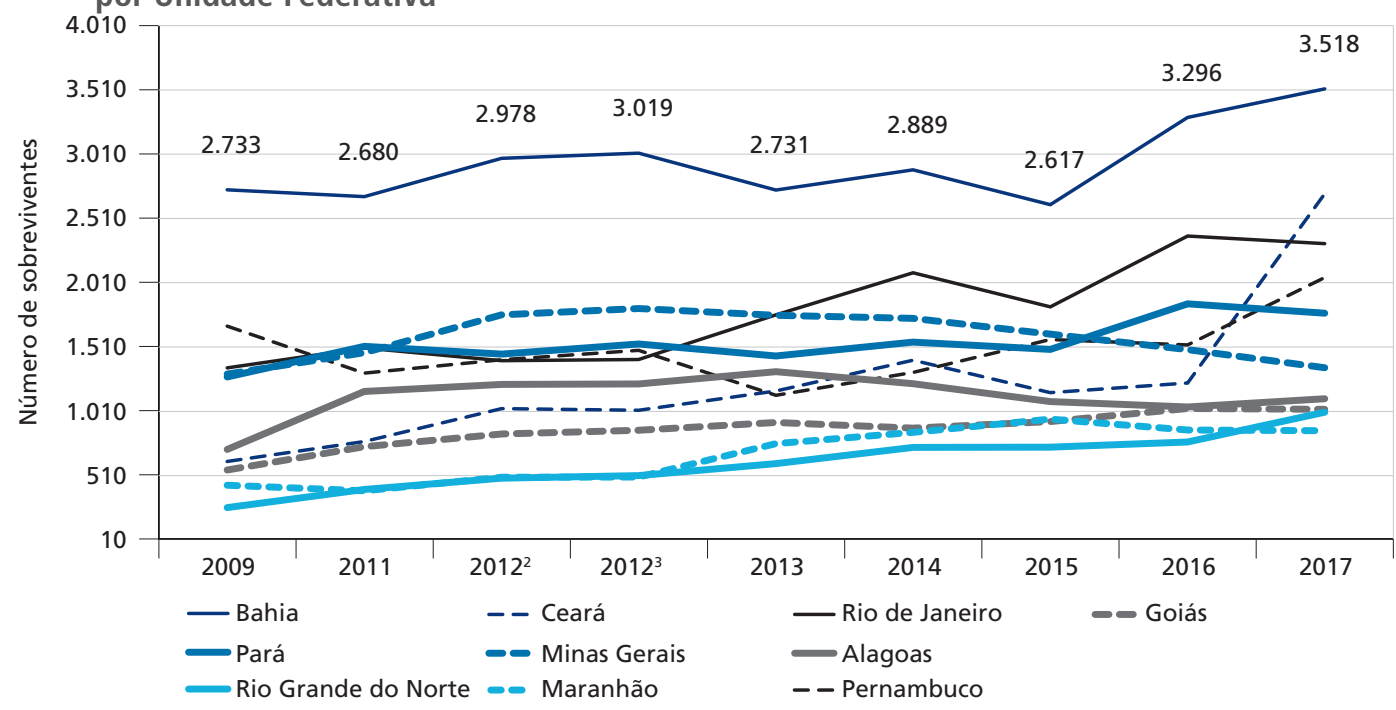

Elaboração das autoras.

Notas: ${ }^{1}$ Apenas as dez UFs que tiveram a maior quantidade de sobreviventes em 2017.

2 Referente à pesquisa PNAD (2012).

3 Referente à pesquisa PNAD Contínua (2012)

\section{GRÁFICO 15}

Sobreviventes de homicídio contra a população branca de doze a dezoito anos de idade, por Região Metropolitana (2012-2017)

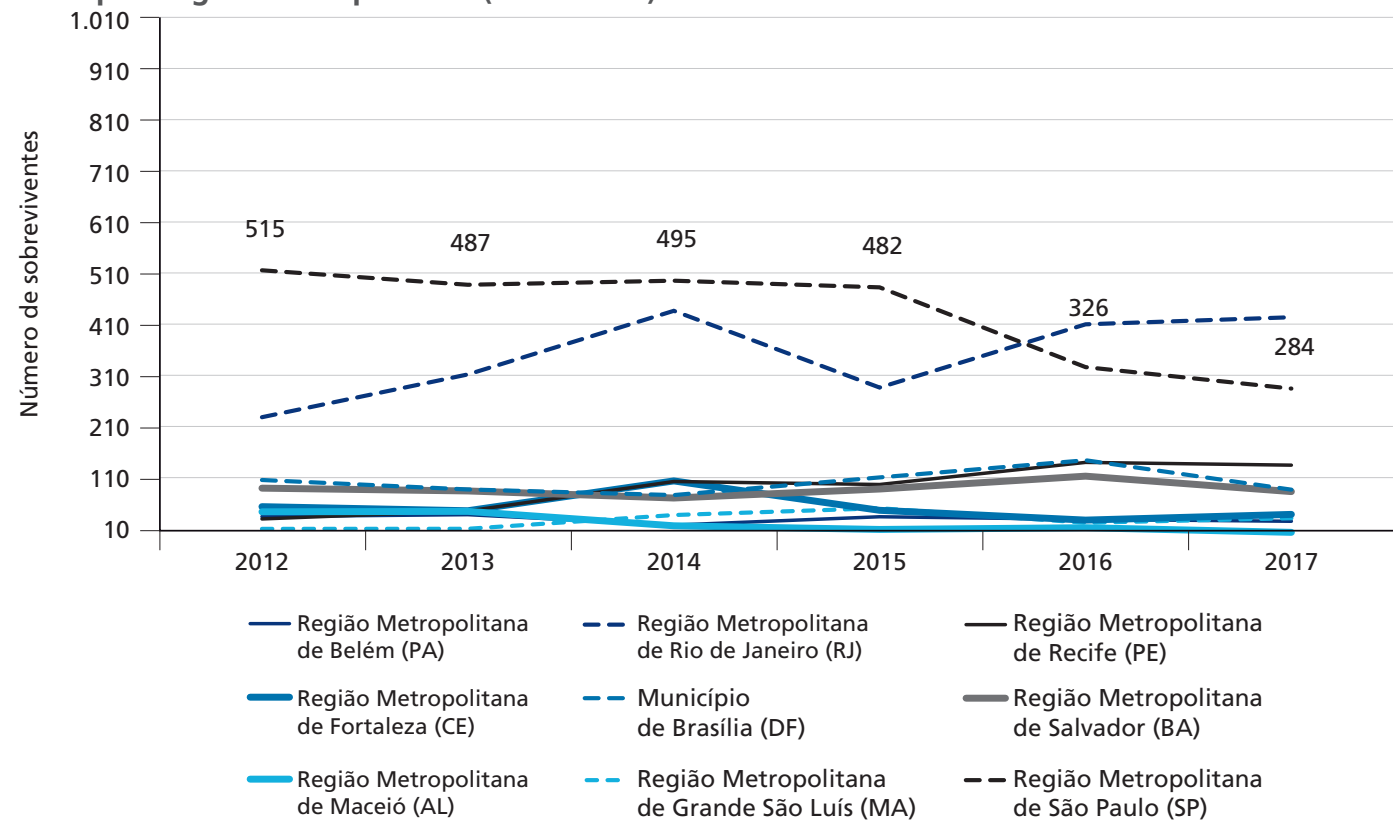

Elaboração das autoras. 


\section{GRÁFICO 16}

Sobreviventes de homicídio contra a população negra de 12 a 18 anos de idade, por Região Metropolitana (2012-2017)

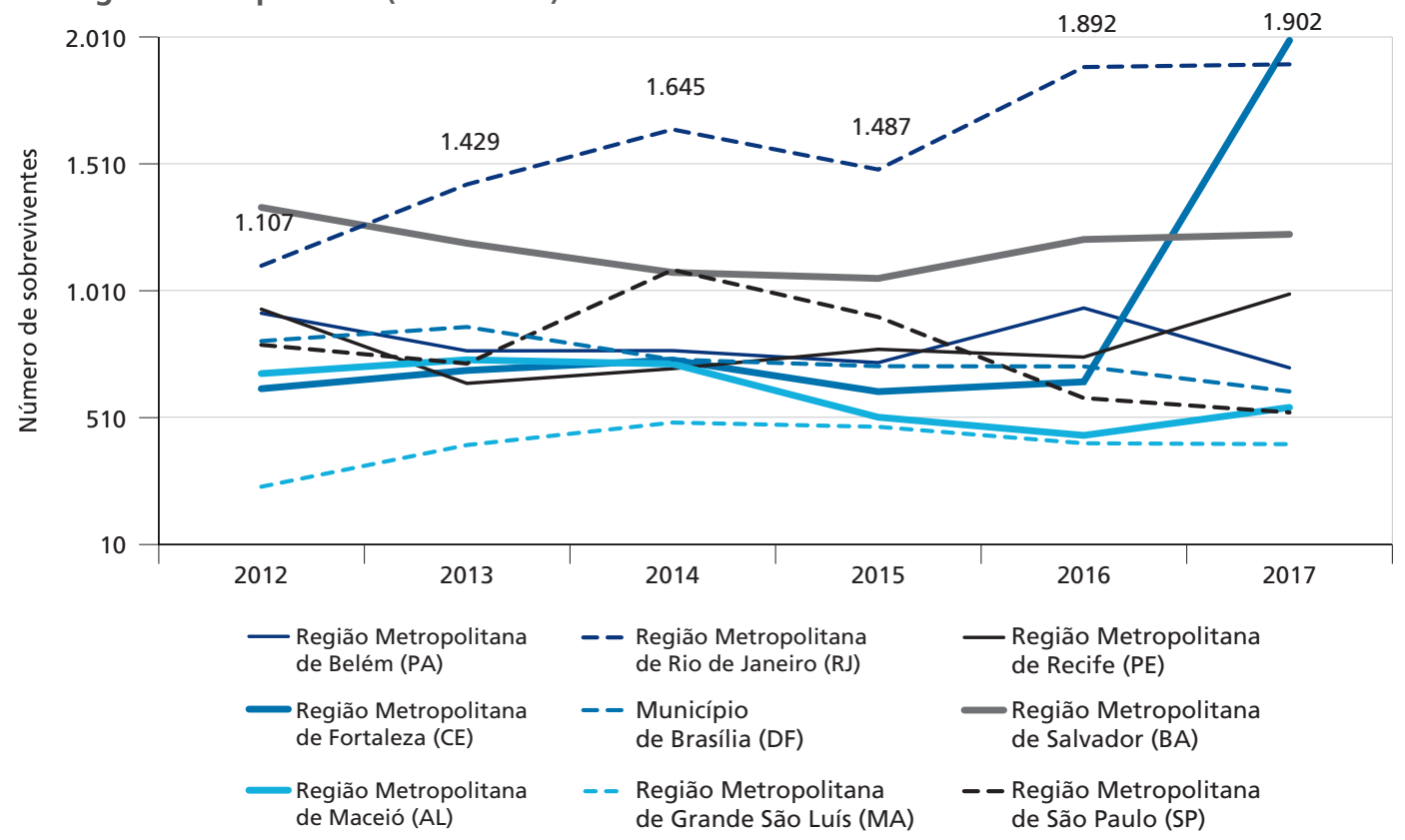

Elaboração das autoras.

\section{GRÁFICO 17}

Sobreviventes de homicídio contra a população branca de zero a onze anos de idade, por Unidade Federativa ${ }^{1}$

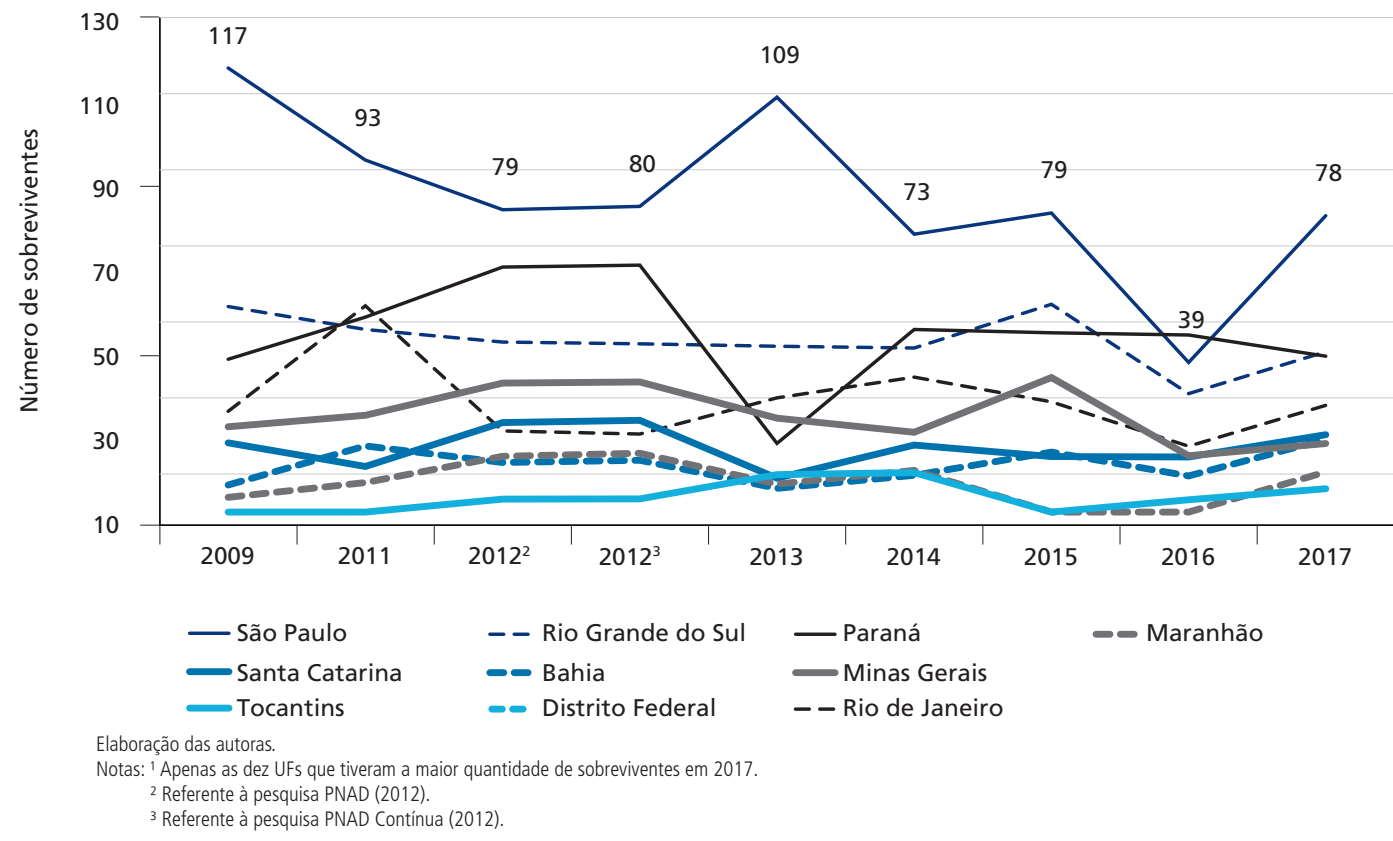


Para sobreviventes de homicídios contra a população negra, há uma tendência à diminuição de sobreviventes relacionados aos homicídios de crianças negras, com zero a onze anos de idade, com exceção dos anos 2012 e 2013. Os valores vão de 871 a 672 sobreviventes entre 2009 a 2017, respectivamente (gráficos 18 e 20). A mesma tendência se consolida para sobreviventes a homicídios perpetrados contra crianças brancas (gráficos 17 e 19). A violência contra crianças no Brasil expõe uma característica das mais repelidas pelo todo social: a desumanização da infância enquanto elemento estruturante das relaçôes sociais na fase adulta.

No limite da ação violenta, o ato de homicídio encerra a vida de crianças. Simultaneamente, confere-se ao Brasil a exclusividade do aspecto mais nocivo à agressão contra a infância - seja questionar o motivo pelo qual no Brasil mata-se criança, seja o imbróglio de algumas RMs e UFs apresentarem quantidades de homicídios que afetam as vidas de famílias no mesmo domicílio, da família estendida, de amigos de vizinhança, de colegas de escola, de colegas de estágio, de colegas de trabalho. A determinação conceitual a ser aferida para um pai viúvo ou para uma mãe viúva do filho/a é diagnóstico a uma política pública que rejeite o status inercial de um Estado no qual há precarização da vida infantil. ${ }^{17}$

17. Usa-se o termo pai viúvo e mãe viúva para caracterizar pais e mães que perderam seus filhos/as por causa de situações trágicas em óbitos diretamente causados por homicídio. 


\section{GRÁFICO 18}

Sobreviventes de homicídio contra a população negra de zero a onze anos de idade, por Unidade Federativa ${ }^{1}$

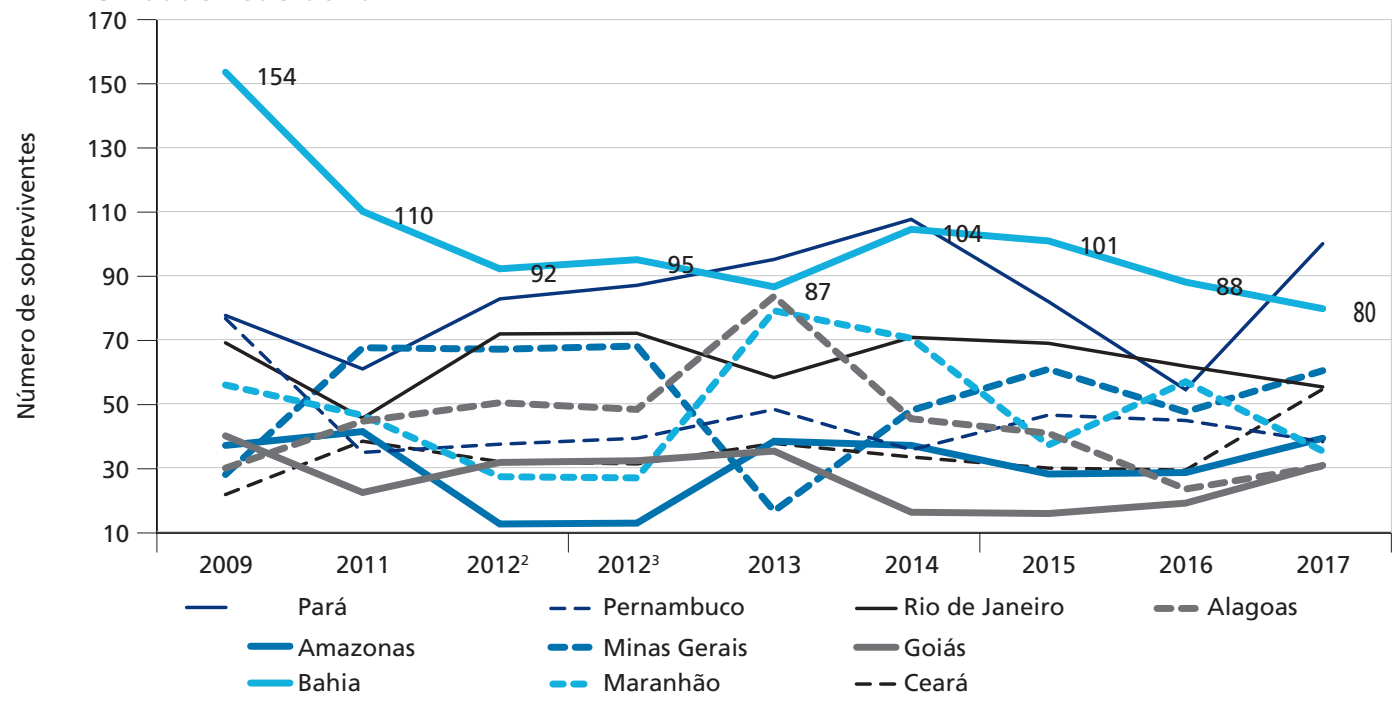

Elaboração das autoras.

Notas: ${ }^{1}$ Apenas as dez UFs que tiveram a maior quantidade de sobreviventes em 2017.

2 Referente à pesquisa PNAD (2012).

${ }^{3}$ Referente à pesquisa PNAD Contínua (2012)

\section{GRÁFICO 19}

Sobreviventes de homicídio contra a população branca de zero a onze anos de idade, por Região Metropolitana (2012-2017)

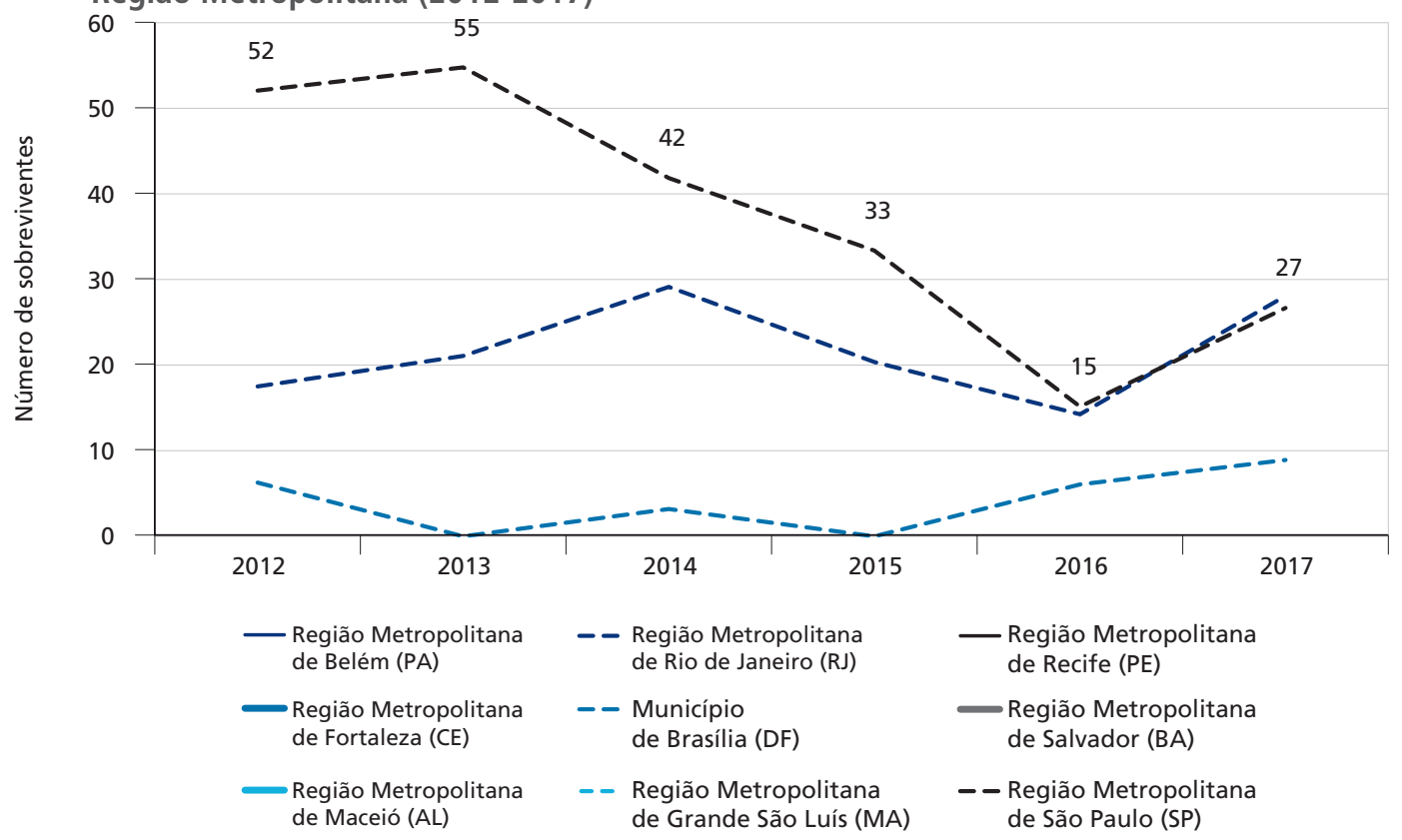

Elaboração das autoras. 


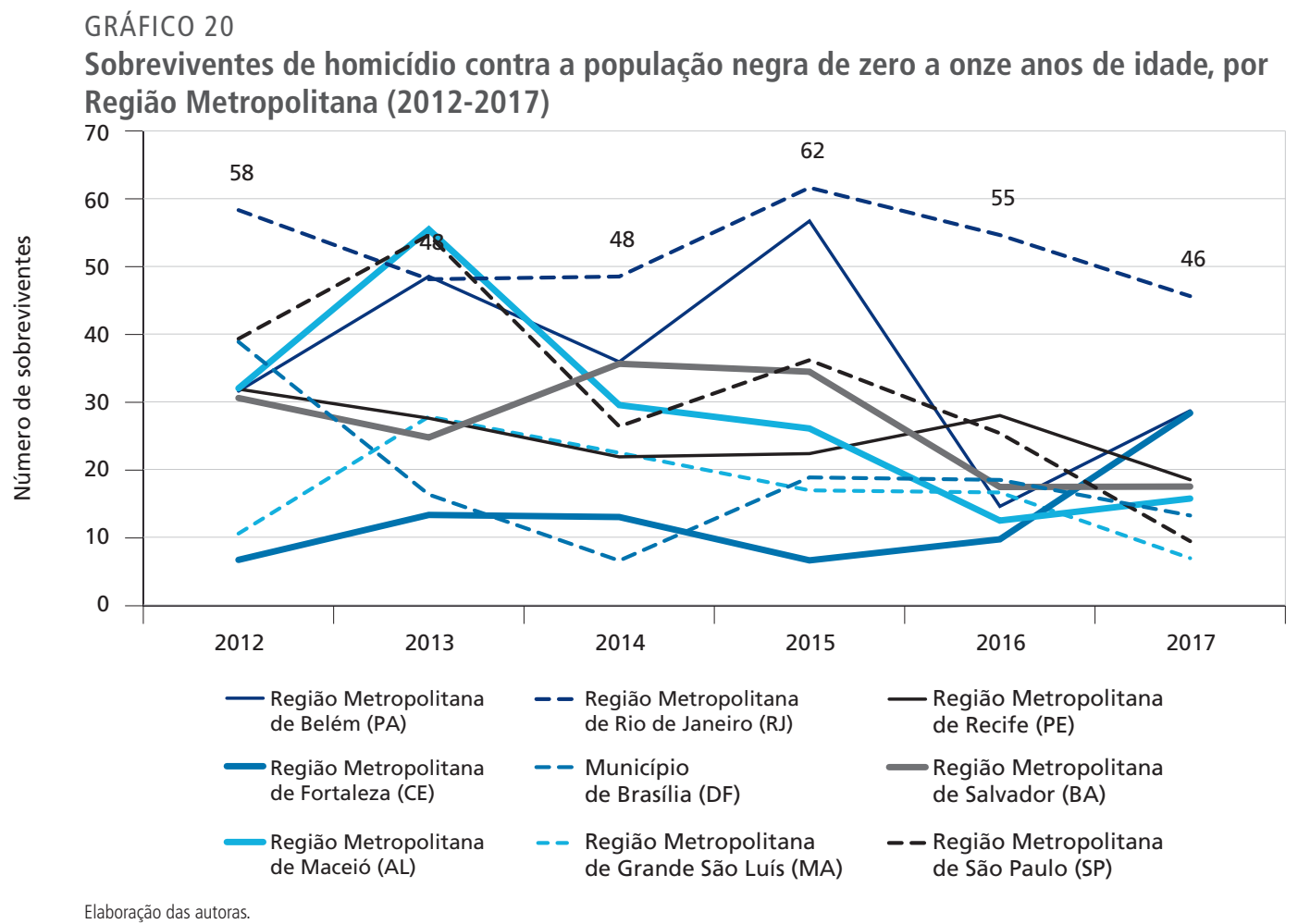

\subsection{Razão de chances em ser sobrevivente de homicídio perpetrado contra pessoas negras em relação ao homicídio de brancos}

A taxa de homicídios contra pessoas negras é acima daquela contra pessoas brancas. Há uma tendência de aumento de homicídios de pessoas negras no século XXI, em contrário à diminuição de homicídios contra pessoas brancas. Nesse sentido, pareceu-nos coerente buscar conhecer a razão de chances entre sobreviventes com relação aos dois grupos de maior incidência de homicídios, negros e brancos. Com o objetivo de analisar a correlação entre ser sobrevivente de homicídio contra brancos e negros, utilizamos a razão de chances (odds ratio) para o cálculo, conforme descrito a seguir.

$$
\begin{aligned}
& \boldsymbol{R C}_{\boldsymbol{B r a n c o s}}=\frac{\text { Número de sobreviventes de homicídios contra a população branca }}{i j} \\
& \boldsymbol{R} \boldsymbol{C}_{\text {Negros }}=\frac{\text { Número de sobreviventes de homicídios contra a população negra }_{i j}}{\text { Número de negros não impactados }{ }_{i j}} \\
& \boldsymbol{R} \boldsymbol{C}_{\boldsymbol{N} / \boldsymbol{B}}=\frac{R C_{\text {Negros }}}{R C_{\text {Brancos }}} \quad \boldsymbol{R C _ { \boldsymbol { B } / \boldsymbol { N } }}=\frac{R C_{\text {Brancos }}}{R C_{\text {Negros }}}
\end{aligned}
$$


em que o número de sobreviventes de homicídios contra a população branca (ou negra) se refere a esses sobreviventes do ano $i$ e exercício $j$. Já o número de não impactados brancos (ou negros) é o total da população branca (ou negra) nesse mesmo período, com o recorte do exercício $j$, menos o número de sobreviventes, ou seja, os impactados não residentes no domicílio da vítima ou os não impactados.

Por exemplo, no E1, em que temos pelo menos um negro no domicílio, seria: número de sobreviventes de homicídios contra a população negra em que o domicílio possui pelo menos um negro, do ano $i$, dividido pelo total de náo impactados desse mesmo ano. O total de impactados se refere ao total da populaçáo negra desse ano menos o número desses sobreviventes. $\mathrm{O}$ mesmo é feito para a população branca (E8) e temos, por fim, o resultado da razão de chances de negros contra brancos, o que pode ser melhor visualizado na tabela 2 .

TABELA 2

Razão de chances de negros/brancos versus brancos/negros em sobreviver a um homicídio, Brasil (2012 a 2017)

\begin{tabular}{|c|c|c|c|c|c|c|c|}
\hline Exercício & Raça $^{1}$ & 2012 & 2013 & 2014 & 2015 & 2016 & 2017 \\
\hline \multirow{2}{*}{1 e 8} & RC Brancos & 0,39 & 0,38 & 0,38 & 0,37 & 0,37 & 0,35 \\
\hline & RC Negros & 2,59 & 2,60 & 2,66 & 2,68 & 2,72 & 2,90 \\
\hline \multirow{2}{*}{2 e 9} & RC Brancos & 0,34 & 0,34 & 0,34 & 0,34 & 0,33 & 0,31 \\
\hline & RC Negros & 2,94 & 2,94 & 2,97 & 2,97 & 3,07 & 3,19 \\
\hline \multirow{2}{*}{3 e 7} & RC Brancos & 0,35 & 0,35 & 0,35 & 0,35 & 0,34 & 0,33 \\
\hline & RC Negros & 2,87 & 2,85 & 2,89 & 2,88 & 2,90 & 3,05 \\
\hline \multirow{2}{*}{4} & RC Brancos & 0,36 & 0,34 & 0,33 & 0,34 & 0,34 & 0,32 \\
\hline & RC Negros & 2,80 & 2,91 & 2,99 & 2,94 & 2,92 & 3,12 \\
\hline \multirow{2}{*}{$4 a$} & RC Brancos & 0,34 & 0,34 & 0,32 & 0,32 & 0,35 & 0,31 \\
\hline & RC Negros & 2,95 & 2,98 & 3,16 & 3,11 & 2,87 & 3,23 \\
\hline \multirow{2}{*}{$4 b$} & RC Brancos & 0,35 & 0,34 & 0,33 & 0,34 & 0,33 & 0,32 \\
\hline & RC Negros & 2,82 & 2,95 & 2,99 & 2,93 & 3,03 & 3,14 \\
\hline \multirow{2}{*}{5} & RC Brancos & 0,35 & 0,36 & 0,32 & 0,32 & 0,35 & 0,31 \\
\hline & RC Negros & 2,86 & 2,78 & 3,11 & 3,09 & 2,86 & 3,21 \\
\hline \multirow{2}{*}{6} & RC Brancos & 0,66 & 0,55 & 0,65 & 0,60 & 0,54 & 0,59 \\
\hline & RC Negros & 1,51 & 1,81 & 1,53 & 1,68 & 1,86 & 1,68 \\
\hline
\end{tabular}

Elaboração das autoras.

Nota: ${ }^{1}$ RC Brancos = razão de chances de brancos/negros; RC Negros = razão de chances de negros/brancos. 
Ainda tomando como exemplo os exercícios 1 e 8 , podemos interpretar a razão de chances da seguinte forma: para o ano de 2017, a chance de ser sobrevivente de homicídio de negro é 2,9 vezes a chance de homicídio de branco; enquanto a chance de ser sobrevivente de homicídio de branco é 0,35 vezes a chance de homicídio de negro.

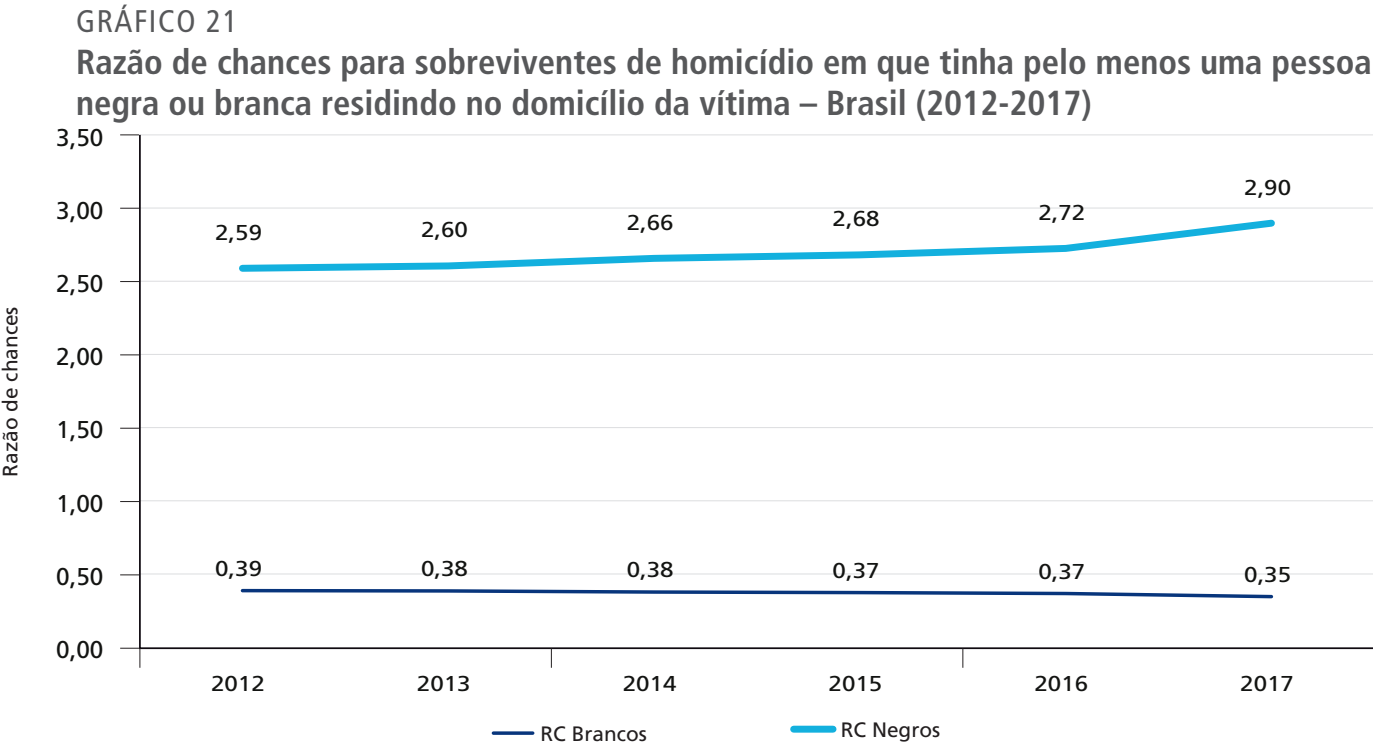

Elaboração das autoras.

No caso dos jovens de quinze a dezenove anos, ainda em 2017, tem-se a maior chance de ser sobrevivente de homicídio contra negros nessa faixa etária, chegando a 3,23 vezes a chance de sobreviventes a homicídios contra brancos (gráfico 22). Além de seguir a tendência à diminuição de impacto nas pessoas por causa de homicídio de jovens brancos, as distâncias entre as linhas expressam as distâncias sociais e raciais para jovens nas mesmas idades, em raça e cor diferente. Ao desagregar a razão de chance para jovens de quinze a dezenove (gráfico 23) e de vinte a 29 anos de idade (gráfico 24) as consideraçóes não são distintas. As maiores razóes de chance para sobreviver a um homicídio de jovem negro em relaçáo a homicídio de jovem branco ocorrem nos primeiros cinco anos da juventude. Para quem residiu no domićlio de um jovem negro entre quinze a 29 anos de idade, no Brasil, entre 2009 a 2017, havia uma chance de duas a três vezes maior para ser vítima indireta de homicídio com relação a quem residiu com um jovem branco. 
GRÁFICO 22

Razão de chances para sobreviventes de homicídio em que tinha pelo menos uma pessoa negra ou branca, de quinze a 29 anos de idade, residindo no domicílio da vítima - Brasil (2012-2017)

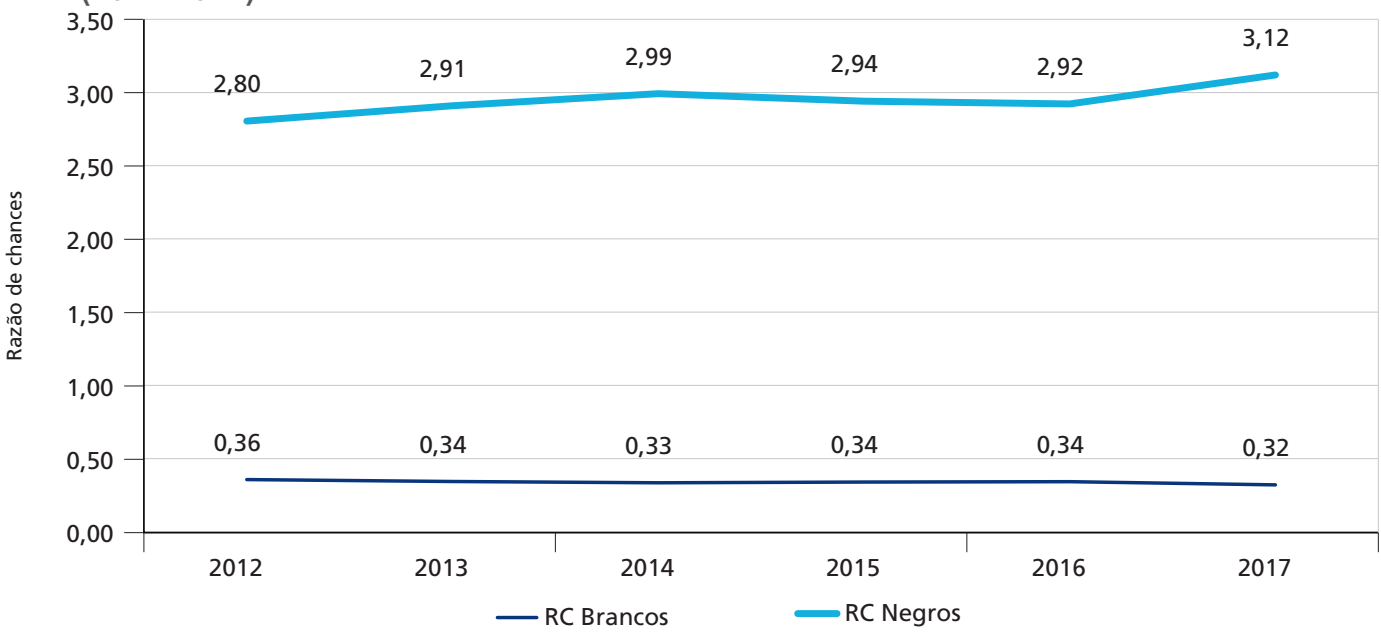

Elaboração das autoras.

GRÁFICO 23

Razão de chances para sobreviventes de homicídio em que tinha pelo menos uma pessoa negra ou branca, de quinze a dezenove anos de idade, residindo no domicílio da vítima Brasil (2012-2017)

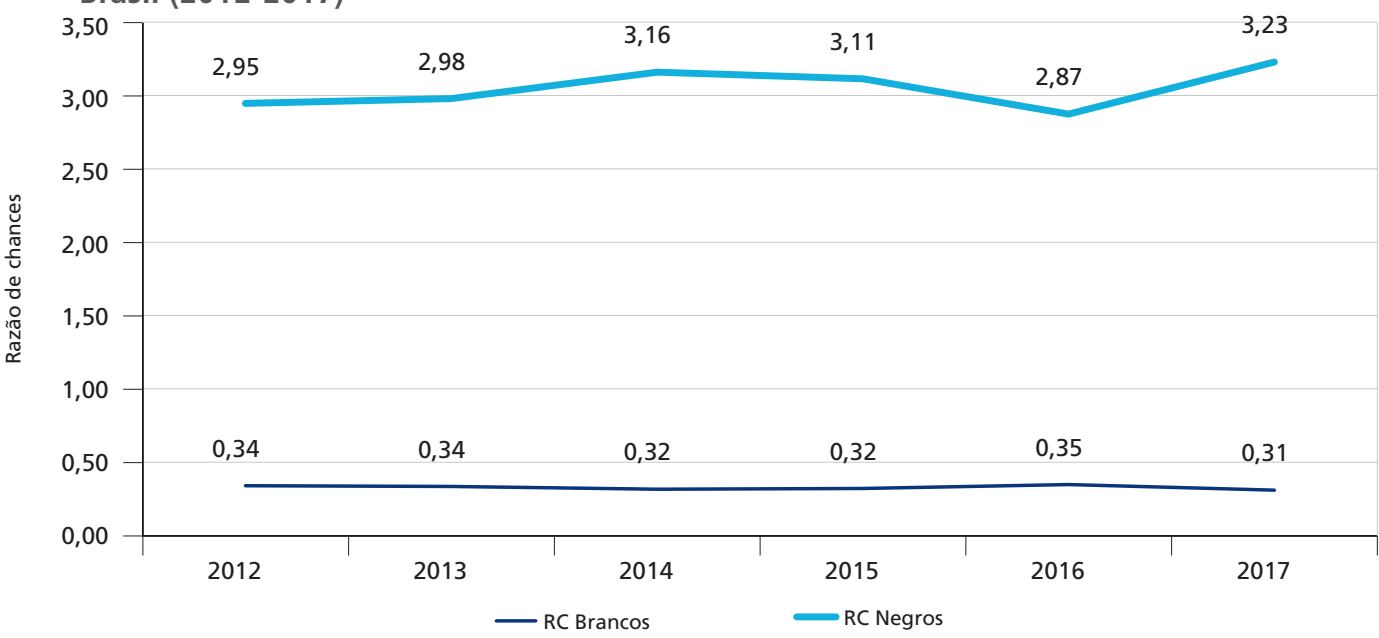

Elaboração das autoras. 


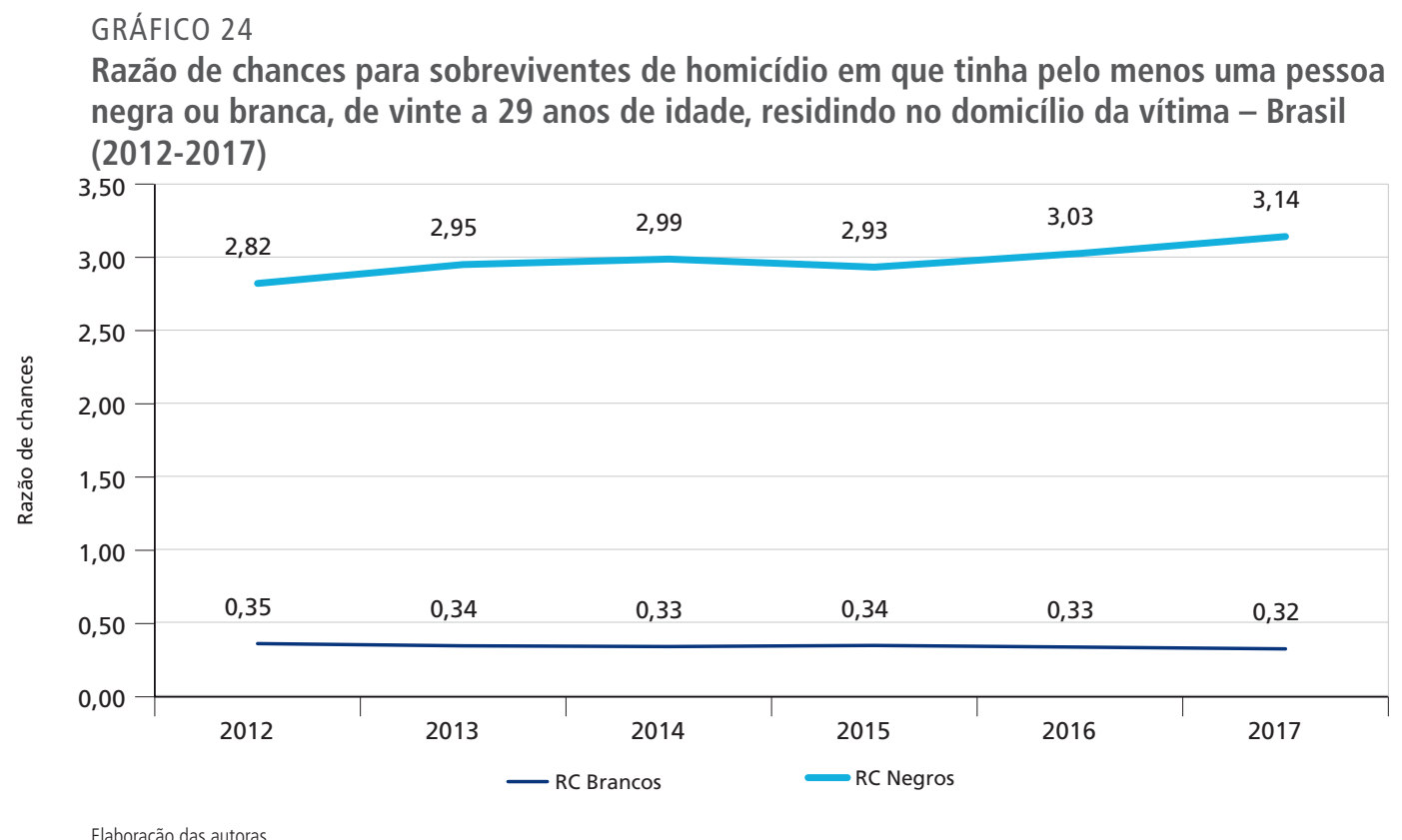

É possível ver que, no decorrer dos anos, a razão de chances de negros contra a de brancos vai aumentando, entáo a chance de ser sobrevivente de homicídio contra a populaçấo negra aumenta com o tempo, enquanto a de brancos diminui. Com adolescentes e crianças, a conclusão é similar. Se, por um lado, em alguns anos do período, a razão de chance para crianças brancas (gráfico 26) é o dobro se comparada a de adolescentes brancos (gráfico 25); por outro lado, a razão de chances de crianças negras é acima daquela de crianças brancas, ou seja, perpetua a estrutura que corresponde a tratamentos diferentes a crianças de raça e cor diversas. 
GRÁFICO 25

Razão de chances para sobreviventes de homicídio em que tinha pelo menos uma pessoa negra ou branca, de doze a dezoito anos de idade, residindo no domicílio da vítima Brasil (2012-2017)

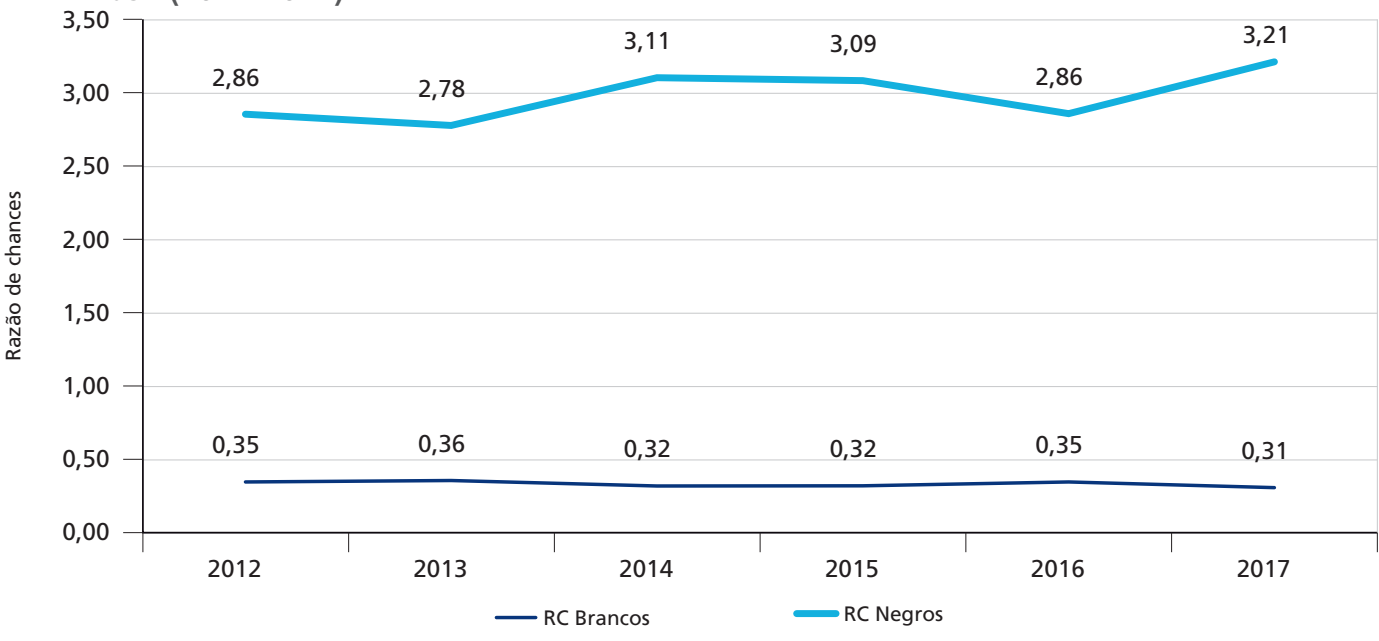

Elaboração das autoras.

GRÁFICO 26

Razão de chances para sobreviventes de homicídio em que tinha pelo menos uma pessoa negra ou branca, de zero a onze anos de idade, residindo no domicílio da vítima - Brasil (2012-2017)

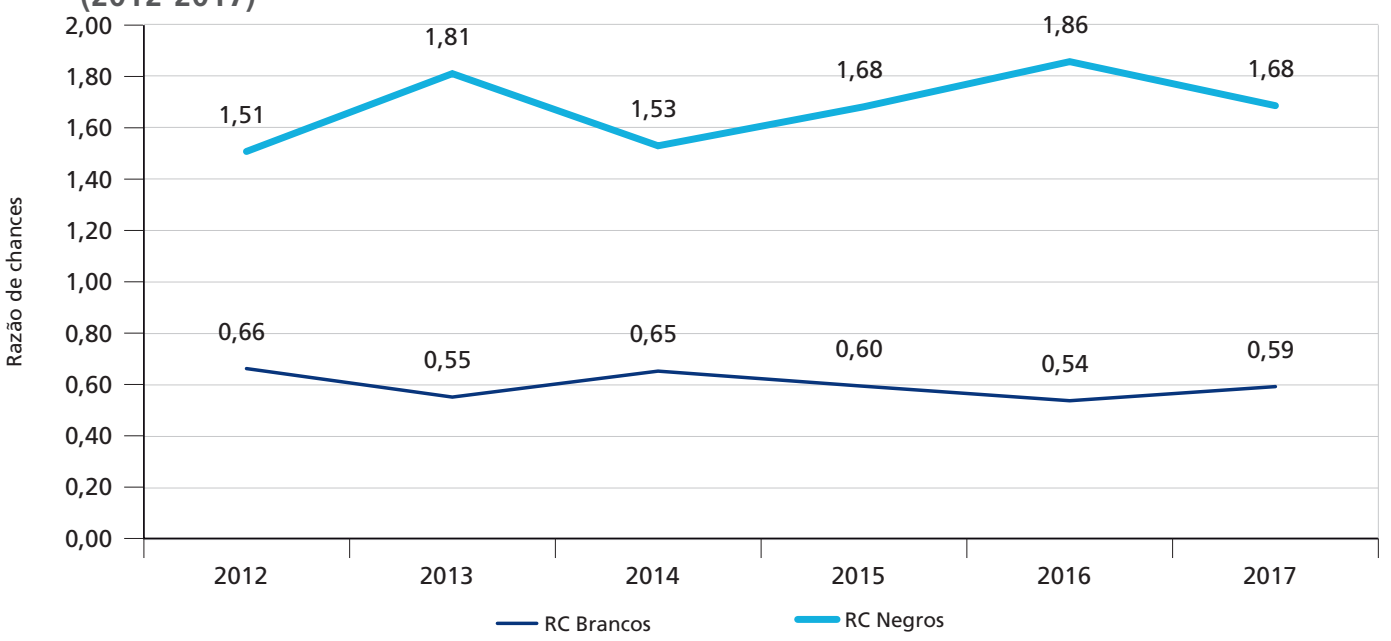

Elaboração das autoras. 


\section{RESULTADOS COM PROTOCOLO DE BOGOTÁ}

Uma outra percepção acerca de uma estimativa de sobreviventes aos homicídios no Brasil é a ampliação dos códigos da CID relacionados a homicídio de acordo com a classificação instituída pelo Protocolo de Bogotá. O instrumento de açôes conjuntas entre Estados que aderiram classifica as informaçóes de homicídios em dois cadastros administrativos muitos comuns nos países: os registros criminais e os atestados de óbito. Os códigos identificados para definir homicídios se coadunam com o CID 10 da Organização Mundial da Saúde (OMS). No âmbito dos atestados de óbitos encontram-se indicadas, para os casos de homicídios: as mortes por agressão (X85-Y05; Y07-Y09); as mortes por intervenção legal (Y35); as mortes por operação de guerra (Y36); e as mortes por sequelas (Y871; Y890; Y891). Os registros criminais determinam mais três códigos: homicídio intencional (O101); homicídio ilegal associado com um conflito armado que não seja equivalente a um crime de guerra (O107); crime de guerra, apenas em casos que resultem em morte (O1013).

Ao incluirmos alguns dos códigos da CID indicados pelo Protocolo de Bogotá, além daqueles mais comumente utilizados, não foram observados qualquer alteração na quantidade de sobreviventes que implicasse mudanças nas consideraçôes anteriormente elaboradas. Replicamos os exercícios de 1 a 9. Para o exercício 1, no qual são estimados a quantidade de sobreviventes perpetrados contra negros/as em que haja pelo menos uma pessoa negra no domicílio da vítima, em 2017 haveriam 105.800, conforme o Protocolo, e 105.759, pelos códigos da CID padrôes. No caso específico do Brasil, no exercício 1, poderíamos afirmar que, aproximadamente, no mínimo 106 mil pessoas foram impactadas pelo homicídio de uma pessoa negra em 2017, seja com os dados do Protocolo, seja com os dados anteriores.

Sem qualquer variação mais acentuada, submetemos os resultados como uma importante perspectiva de observarmos outras classificaçóes para homicídios que possam ser relevantes em alguns países da América do Sul e América Central. Entretanto, apresentaram-se alteraçóes menos explícitas nas circunstancias de se calcular uma opçáo de estimativa da quantidade de sobreviventes no Brasil.

Para o caso de haver pelo menos uma pessoa branca no domicílio, em 2017, segundo o exercício 8 , a variação de 38 pessoas para cima não chega a $0,2 \%$. Se desagregarmos 
os dados por idade, juventude, adolescente e crianças as proporçóes são ainda menores e não refutam nossa impressão inicial. Em 2017, de acordo com exercício 4, sobreviveram 78.573 pessoas para homicídio de jovem negro e 16.928 de jovem branco, pelo Protocolo de Bogotá; enquanto 78.553 e 16.957 pessoas, para respectivos jovens, pelo padrão brasileiro. No caso de sobreviventes a homicídios perpetrados contra adolescentes de doze a dezoito anos de idade, nexercício 5, a quantidade foi de 4.416 para brancos e 23.268, para negros. Para sobreviventes a homicídios contra crianças de zero a onze anos de idade, no exercício 6, o índice para brancos era de 303 e para negras, 672 .

Ao fim então, cumpre resgatar que, apesar de não ser possível somar os totais para sobreviventes a homicídios perpetrados contra pessoas brancas e negras, a estimativa dividida em nove exercícios com recorte por raça/cor, por idade, por geografia cumpre enquanto base para executar uma possível política às vítimas indiretas de homicídios.

\section{CONSIDERAÇÕES FINAIS}

Um consenso em estimativas é que sempre são passíveis de discordâncias. Aceitar o convite de demais colegas da Diretoria de Estudos Sociais para avançar em exercícios que pudessem apresentar resultados de quantificação de sobreviventes é um desafio consequente ao reconhecimento de uma iniciativa. Com certeza, nos permitimos trabalhar mais, testar mais, tentar mais. E esse processo consolida nossa colaboração para uma possível política pública de caráter específico direcionada para o principal grupo vítima indireta aos homicídios no país. Espera-se que o conhecimento do público focal implique a elaboração e execução de uma política. Na urgência, pois, de algum modo desenhar condicionalidades para as políticas existentes, com objetivo de minimizar as consequências da perda trágica de uma pessoa próxima.

O primeiro contato com o grupo de pessoas sobreviventes surgiu diante da demanda de elaboração de um parecer em 2018 para um Texto para Discussão (Júnior Lima, no prelo). O texto propunha ao Estado observar as vivências de familiares e amigos/ as, pessoas próximas à vítima de homicídio que eram tornadas co-vítimas, ou vítimas secundárias, após a perda de um ente próximo. Inclusive relatam-se estórias que foram contadas pelos diversos meios de comunicação e mídias sociais estudadas enquanto objeto empírico, de casos de famílias que adoeceram mentalmente e fisicamente durante 
o processo de luto e diante das complicações em função da ausência da pessoa vítima de homicídio. Assim, esse texto nos encaminha para a pergunta de problema sobre a quantidade de sobreviventes a homicídios no Brasil de acordo com o perfil deste grupo por raça e cor; por idade; por sexo/gênero; por localização geográfica.

$\mathrm{Na}$ busca de estudos e de modelos, no Brasil e demais países que houvessem calculado estimativas de sobreviventes, nos deparamos com uma pesquisa inspiradora executada por Soares, Miranda e Borges (2005). A metodologia dos pesquisadores e da pesquisadora baseou-se principalmente na produção de dados primários com aplicação de questionário por meio de entrevista. Inicialmente, analisaram a tendência constatada de crescimento do número de homicídios no Brasil, desenvolvendo a pesquisa sobre vítimas ocultas, vítimas secundárias a homicídios e a mortes violentas, que além de homicídios incluem suicídios, acidentes de trânsito, atropelamento, queda ou acidente de trabalho com foco nos efeitos individuais e para o coletivo.

Nossa metodologia para quantificar sobreviventes a homicídios no Brasil nem se pretende universal, nem única. Porquanto, visualizar alguma coerência de um grupo que se aproxima pelo lugar de vítima indireta é uma alternativa aos estudos de estimavas de sobreviventes. Uma opção é desenhar metodologias específicas para cada território. Algumas características são comuns às vítimas de homicídios, então desenhar aspectos comuns aos sobreviventes cumpre outra demanda de continuidade aos estudos de perfil e de diagnóstico do grupo focal e cliente de uma possível política pública aos sobreviventes.

Finalizamos com o convite aos demais pesquisadores para a continuidade de propostas de metodologias de estimativas de sobreviventes. Ao acrescentarmos aos resultados aqui apresentados as consideraçóes de outras pesquisadoras/es, provavelmente nos incentivarão a reinventar-se e, se necessário, adaptar e modificar nossas metodologias. Desejamos, então, a devida atenção aos sobreviventes impactados por homicídios no Brasil, que seja mais importante que para além das quantificações.

\section{REFERÊNCIAS}

CARVALHO, A. X. Y. et al. Mapeamento de taxas bayesianas, com aplicaçáo ao mapeamento de homicídio. Rio de Janeiro: Ipea, 2011. (Texto para Discussão, n. 1662). 
CARVALHO, A. X. Y. et al. Custos das mortes por causas externas no Brasil. Brasília: Ipea, 2007. (Texto para Discussão, n. 1268).

CARVALHO, Alexandre. CERQUEIRA, Daniel. LOBÃO, Valdir.

CRCVC - CANADIAN RESOURCE CENTRE FOR VICTIMS OF CRIME. Homicide Survivors: dealing with grief. Ontario: CRCVC, 2005.

CERQUEIRA, D. Mortes violentas náo esclarecidas e impunidade no Rio de Janeiro. Rio de Janeiro: Ipea, 2012. (Texto para Discussão, n. 1697).

O mapa dos homicídios ocultos no Brasil. Brasília: Ipea, 2013. (Texto para Discussão, n. 1878).

Avaliando a efetividade da Lei Maria da Penha. Brasília: Ipea, 2015. (Texto para Discussão, n. 2048).

CERQUEIRA, D.; LOBÃO, V. Condicionantes sociais, poder de polícia e o setor de produção criminal. Rio de Janeiro: Ipea, 2003a. (Texto para Discussão, n. 957).

Criminalidade: social versus polícia. Rio de Janeiro: Ipea, 2003b. (Texto para Discussão, n. 958).

CERQUEIRA, D.; LOBÃO, V.; CARVALHO, A. X. O jogo dos sete mitos e a miséria da segurança pública no Brasil. Rio de Janeiro: Ipea, 2005. (Texto para Discussão, n. 1144).

CERQUEIRA, D. COELHO, D. S. C. Democracia Racial e homicídios de jovens negros na cidade partida. Brasília: Ipea, 2017. (Texto para Discussão, n. 2267).

CERQUEIRA, D. R. C.; MELLO, J. M. P. Menos armas, menos crimes. Brasília: Ipea, 2012. (Texto para Discussão, n. 1721).

CERQUEIRA, D. et al. (Coord.). Atlas da Violência 2018. Brasília: Ipea; FBSP, 2018.

CERQUEIRA, D. R. C. et al. Uma avaliação de impacto de política de segurança pública: O programa Estado Presente do Espírito Santo. Brasília: Ipea, 2020. (Texto para Discussão, n. 2543).

COSTA, D. H.; NJAINE, K.; SCHENKER, M. Repercussões do homicídio em famílias das vítimas: uma revisão da literatura. Ciência \& Saúde Coletiva, Rio de Janeiro, v. 22, n. 9, 2017.

Data SUS/SIM. Sistema de Informação sobre Mortalidade. Ministério da Saúde.

DAVIS, A. A democracia da abolição: para além do império, das prisões e da tortura. Rio de Janeiro: Difel, 2009. 
Estariam as prisóes obsoletas? Rio de Janeiro: Difel, 2018.

FANON, F. Os condenados da terra. Juiz de Fora: Editora UFJF, 2005.

GARCIA, L. P.; SILVA, G. D. M. Mortalidade de mulheres por agressôes no Brasil: perfil e estimativas corrigidas (2011-2013). Brasília: Ipea, 2016. (Texto para Discussão, n. 2179).

GBOWEE, L.; MITHERS, C. Guerreiras da paz: como a solidariedade, a fé e o sexo mudaram uma nação em guerra. São Paulo: Companhia das Letras, 2012.

GILMORE, R.W. Golden gulag: prisons, surplus, crisis, and opposition in globalizing California. California: University of California Press, 2007.

GOES, F L.; LOPES, D. A. Metodologia para quantificação de sobreviventes aos homicídios perpetrados contra populaçáo negra no Brasil. Rio de Janeiro: Ipea, 2019. (Texto para Discussão, n. 2489).

HERTZ, M. F.; PROTHROW-STITH, D.; CHERY, C. Homicide survivors: research and practice implications. American Journal of Preventive Medicine, Michigan, v. 29, n. 5, p. 288-295, 2005.

IBGE - INSTITUTO BRASILEIRO DE GEOGRAFIA E ESTATÍSTICA. Censo Demográfico 2010. Rio de Janeiro, IBGE, 2010.

PNAD Contínua 2012 - 2017. Microdados da Pesquisa Nacional por Amostra de Domicílios Contínua. Rio de Janeiro: IBGE, 2017.

IPEA - INSTITUTO DE PESQUISA ECONÔMICA APLICADA. Políticas sociais: acompanhamento e análise. Brasília: Ipea, 2012.

Políticas sociais: acompanhamento e análise. Brasília: Ipea, 2014.

JÚNIOR LIMA, A. T. Memória, dor e sofrimento: o genocídio consentido da população negra e os silêncios do Estado. Brasília: Ipea, 2018. No prelo.

MBEMBE, A. Necropolítica: Biopoder, soberania, estado de exceção, política da morte. Traduzido por Renata Santini. São Paulo: n-1 ediçóes, 2018.

MOURA, T. W. Política pública de prevenção de homicídios e alternativas de ação coletiva. Rio de Janeiro: Ipea, 2010. (Texto para Discussão, n. 1513).

NASCIMENTO, A. D. O genocídio do negro brasileiro: processo de um racismo mascarado. 1. ed. São Paulo: Perspectivas, 2016.

OSÓRIO, R. G. Sistema classificatório de “cor ou raça” do IBGE. Brasília: Ipea, 2003. (Texto para Discussão, n. 0996).

PESSOA, M. S. Segurança pública no Rio de Janeiro: um estudo dos homicídios dolosos 
entre 2003 e 2014. Rio de Janeiro: Ipea, 2016. (Texto para Discussão, n. 2204).

RIVERO, P. S. Distribuição desigual dos direitos humanos e da cidadania: áreas de concentração de vítimas de homicídio e ação policial no município do Rio de Janeiro. Brasília: Ipea, 2010. (Texto para Discussão, n. 1499).

RODRIGUES, R. I. Moradia precária e violência na cidade de Sáo Paulo. Rio de Janeiro: Ipea, 2006. (Texto para Discussão, n. 1187).

RODRIGUES, R. I.; RIVERO, P. S. Áreas de concentração das vítimas de violência no município do Rio de Janeiro (2002-2006). Brasília: Ipea, 2012. (Texto para Discussão, n. 1698).

THOMÉ, D. B; VONBUN, C. Análise do impacto de gastos públicos com programa de transferência de renda sobre a criminalidade. Brasília: Ipea, 2017. (Texto para Discussão, n. 2315).

SOARES, G. A. D.; MIRANDA, D.; BORGES, D. As vítimas ocultas da violência urbana no Rio de Janeiro. Rio de Janeiro: CESeC, 2005.

WAISELFISZ, J. J. Mapa da Violência 2012: a cor dos homicídios no Brasil. Rio de Janeiro: CEBELA, FLACSO; Brasília: SEPPIR/PR, 2012.

Mapa da Violência 2013: homicídios e juventude no Brasil. Rio de Janeiro: CEBELA, FLACSO; Brasília: SEPPIR/PR, 2013.

WIJK, A. V.; LEIDEN, I. V; FERWERDA, H. Murder and the long term impact on co-victims: a qualitative, longitudinal study. Netherlands: International Review of Victimology, 2016.

ZINZOW, H. M., et al. Losing a loved one to homicide: prevalence and mental health correlates in a national sample of young adults. Journal of Traumatic Stress, Utah, v. 22, n. 1, p. 20-27, 2009. 

Ipea - Instituto de Pesquisa Econômica Aplicada

\section{Assessoria de Imprensa e Comunicação}

\section{EDITORIAL}

Chefe do Editorial

Reginaldo da Silva Domingos

\section{Assistentes da Chefia}

Rafael Augusto Ferreira Cardoso

Samuel Elias de Souza

\section{Supervisão}

Camilla de Miranda Mariath Gomes

Everson da Silva Moura

\section{Editoração}

Aeromilson Trajano de Mesquita

Anderson Silva Reis

Cristiano Ferreira de Araújo

Danielle de Oliveira Ayres

Danilo Leite de Macedo Tavares

Jeovah Herculano Szervinsk Junior

Leonardo Hideki Higa

\section{Capa}

Danielle de Oliveira Ayres

Flaviane Dias de Sant'ana

\section{Projeto Gráfico}

Renato Rodrigues Bueno

The manuscripts in languages other than Portuguese published herein have not been proofread.

\section{Livraria Ipea}

SBS - Quadra 1 - Bloco J - Ed. BNDES, Térreo

70076-900 - Brasília - DF

Tel.: (61) 2026-5336

Correio eletrônico: livraria@ipea.gov.br 

Composto em adobe garamond pro 12/16 (texto) Frutiger 67 bold condensed (títulos, gráficos e tabelas) Brasilia-DF 



\section{Missão do Ipea}

Aprimorar as políticas públicas essenciais ao desenvolvimento brasileiro por meio da produção e disseminação de conhecimentos e da assessoria ao Estado nas suas decisões estratégicas.

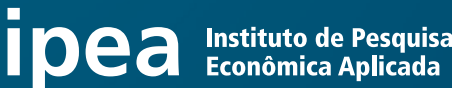 \\ MINISTÉRIO DA \\ ECONOMIA

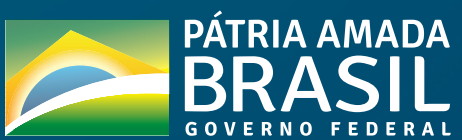

